\title{
Pricing Behavior Indicators and the Factors Affecting It: Evidence from Refah Stores' Price Microdata
}

\author{
Seyed Ali Madanizadeh ${ }^{1}$ \\ Masoumeh Saedi ${ }^{2}$ \\ madanizadeh@sharif.edu
}

Received: 06/02/2021 | Accepted: 06/06/2021

\begin{abstract}
Price stickiness, measured by indicators like frequency and duration of price changes, determines the short-term real effects of monetary policy in the economy. Discovering the factors affecting price adjustment allows the monetary policymaker to predict the changes in pricing behavior by monitoring the changes of these influential factors. Employing microdata of 84 million monthly price observations from the Refah chain stores in Iran shows that on average, goods' prices did not last more than 2.52 months and the price of at least 47.34 percent of examined goods changed every month, meaning that the price stickiness is pretty weak in Iran's economy and there is a little room for the monetary authority to influence the real economy. Moreover, as regards the factors affecting the price-setting behaviors, the results show that the frequency of price changes has a positive threshold correlation with the inflation rate; As the inflation crosses $18 \%$, the intensity of this positive effect decreases. It is important to note that inflation is not the only factor explaining the pricing behavior, but the growth rate of liquidity, GDP and exchange rate also have significant positive effects on the frequency and magnitude of price changes.
\end{abstract}

Keywords: Pricing Behavior, Price Stickiness, Frequency of Price Changes, Magnitude of Price Changes, Duration of Price Changes.

JEL Classification: E30, E31, E5.

1. Assistant Professor, Faculty of Economics, Sharif University of Technology, Tehran, Iran (Corresponding Author)

2. M.A. in Economics, Sharif University of Technology, Tehran, Iran. 


\section{شاخص هاى رفتار قيمتخذارى و عوامل موثر بر

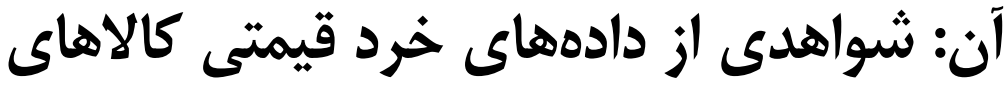

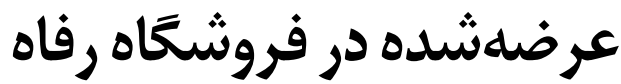

madanizadeh@sharif.edu

سيدعلى مدنىزاده

استاديار اقتصاد دانشكاه صنعتى شريف، تهران، ايران (نويسنده مسئول).

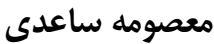

مقاله بزوهشى

كارشناسى ارشد اقتصاد، از دانشكاه صنعتى شريف، تهران، ايران.

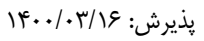

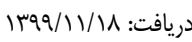

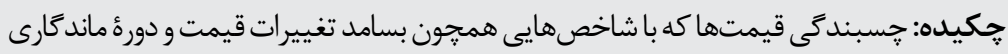

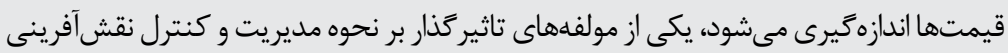

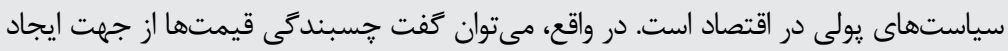

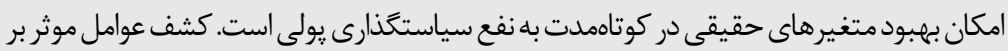

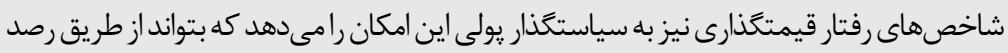

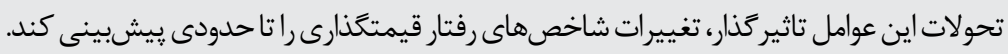

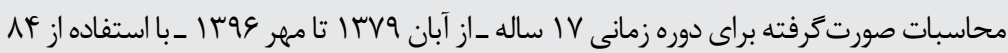

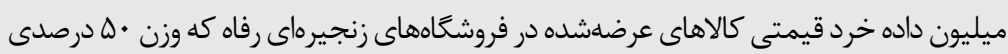

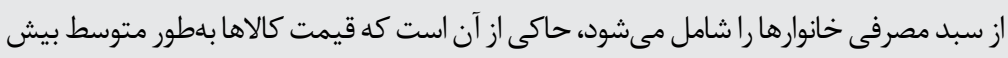

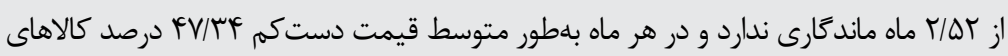

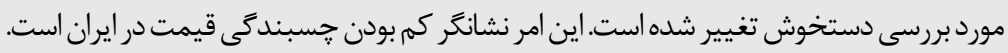

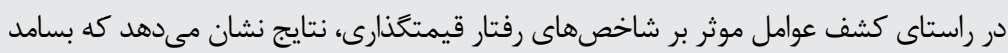

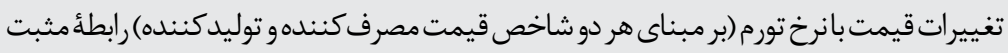

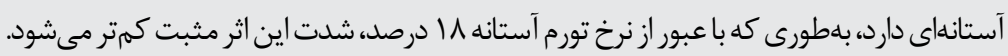

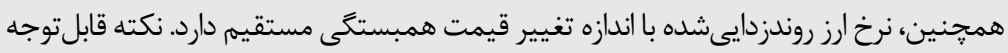

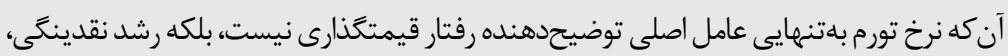

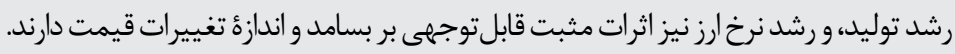

كليدوازهها: رفتار قيمتخذارى، جسبندگى قيمت، بسامد تغييرات قيمت، اندازه تغييرات قيمت، دوره ماندكارى قيمت.

طبقهبندى E5, E31, E30 :JEL. 


\section{مقدمه}

اين يزوهش با استفاده از NF ميليون داده قيمتى ماهانه فروشگاههاى زنجيرهاى رفاه براى دوره

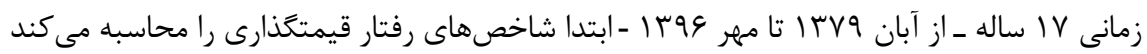
و سيس ميزان و نوع رابطه آنها با نرخ تورم (خطى، درجه دوم يا آستانهاى) را شناسايى مىنمايد.

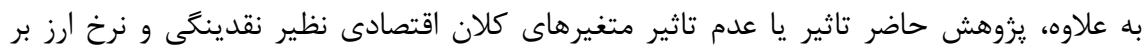

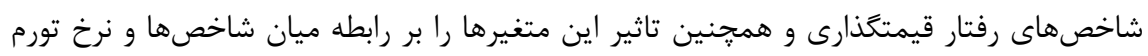
بررسى مى كند.

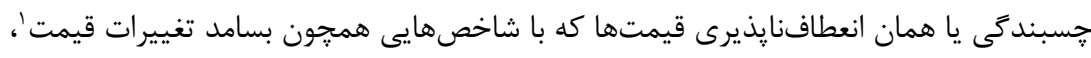

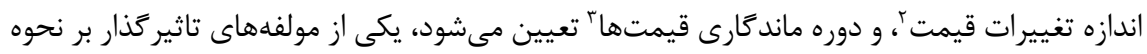

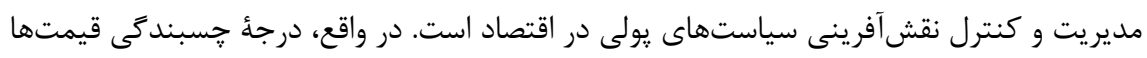
ميزان تاثير يول بر متغيرهاى حقيقى اقتصاد ازجمله توليد و بيكارى را در كوتاهمدت تعيين مى كند.

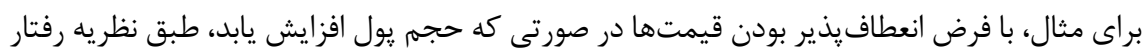
عقلايى، مردم به اين واقعيت واقفند كه نسبت دستمزدها و قيمتها تغييرى نكرده است. در نتيجئه اين روند تمام نوسانات حجم يول روى قيمت تخليه خواهد شد و افزايش حجم يول تاثيرى بر هيج متغير

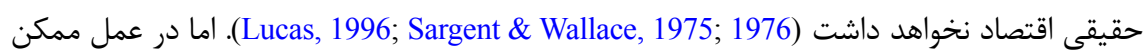
است به علت هزينهبر بودن :بردازش اطلاعات و فرايند تغيير قيمت، قيمتها انعطاف يذيرى خود را

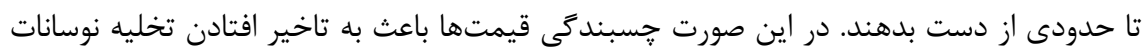

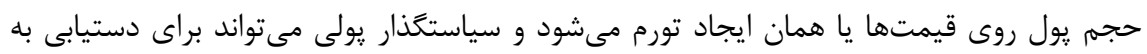

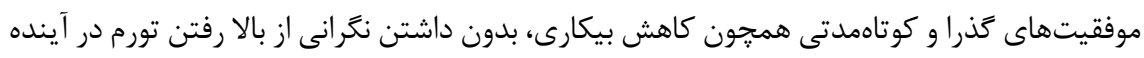

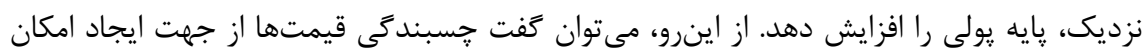

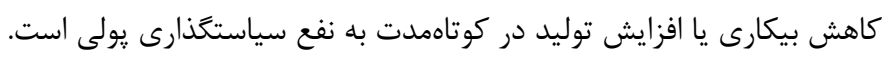

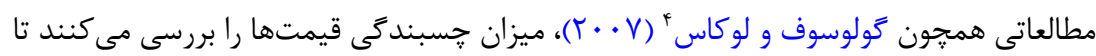
به ملاحظات سياستخذاران در خصوص توانايىهاى سياست يولى براى دستيابى به اهداف كوتاهمدت

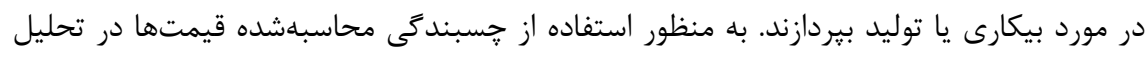

1. Frequency of Price Changes

2. Magnitude of Price Changes

3. Duration

4. Golosov \& Lucas 
ميزان كارامدى سياستهاى يولى، عوامل موثر بر جسبندگى قيمتها نيز بايد مورد بررسى قرار گيرند.

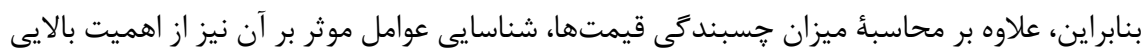
برخوردار است. اين مهمم در سالهاى اخير مورد توجه يزوهشگران اين حوزه واقع شده است. ازجمله

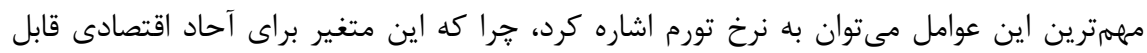
مشاهده و ملموس است و مىتواند بلهطور مستقيم بر تصميمهاى بنعاههاى اقتصادى درباره تعديل

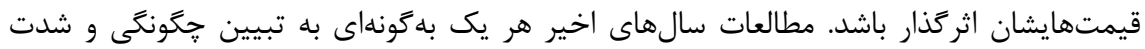
تاثيريذيرى بسامد و اندازه تغيير قيمت از نرخ تورم يرداخته و برخى از آنها، بسامد و اندازه تغييرات

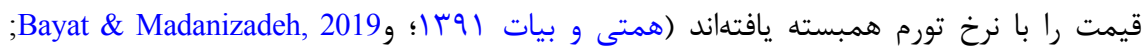

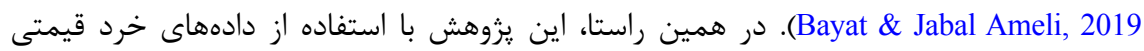

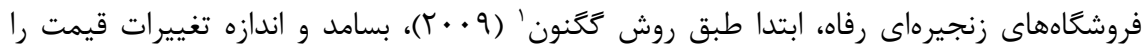

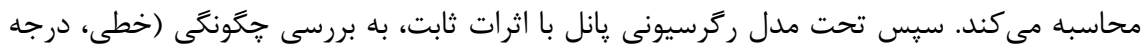
دوم يا آستانهاى) و شدت تاثيريذيرى شاخصهاى رفتار قيمتخذارى از نرخ تورم مصرفكننده و توليدكننده و ساير متغيرهاى كلان اقتصادى مى يردازد. تفاوت اصلى يزوهش حاضر نسبت به مطالعات يِيشين انجامشده در ايران را مىتوان در دادههاى مورد استفاده دانست. در اين يزوهش از داده خرد فروشكاههاى زنجيرهاى رفاه مشتمل بر بر بر ميليون

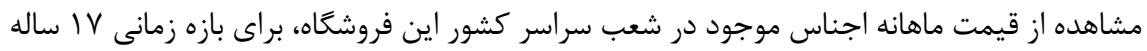

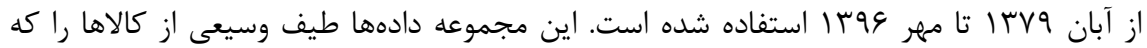

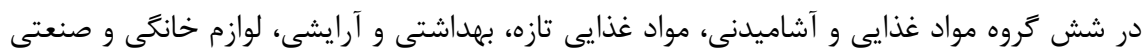

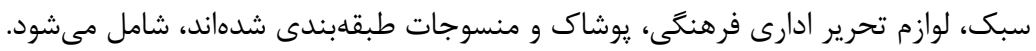

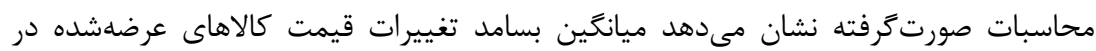

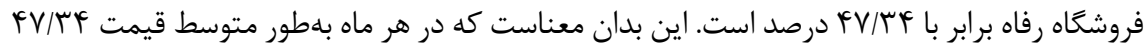
درصد از كل كالاهاى فروشگاههاى رفاه تغيير كرده است. همجنين، ميانگَين دوره ماندكارى ضمنى

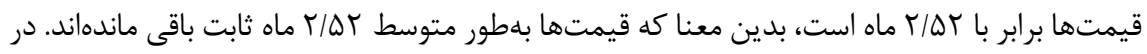
مورد رابطه ميان شاخصهاى رفتار قيمتخذارى با نرخ تورم و ساير متغيرهاى كلان اقتصادى مشاهده مىشود كه بين بسامد تغيير قيمت و نرخ تورم رابطةٔ مستقيم آستانهاى (با نرخ تورم آستانهاى 1 | درصد) بهَّونهاى برقرار است كه شدت اين رابطه بعد از آستانه كمتر مى بـود. بهطورى كه به با ثبات 
ساير شرايط، افزايش يك واحد درصد تورم، بسامد تغيير قيمت را در زمان پايينتر بودن تورم از

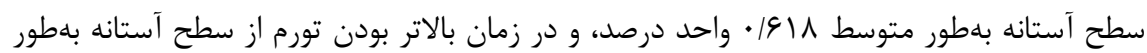

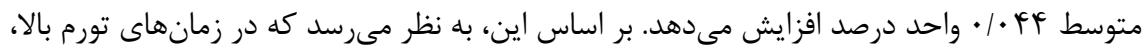
قيمتكذاران جون به كاهش قدرت خريد مردم در سطح جامعه واقف هستند، كمتر از زمانهاى تورم يايين قيمت كالاها را تغيير مىدهند. به علاوه، نشان داده مىشود كه نقدينكى اثر مثبت بر بسامد تغييرات قيمت دارد، بهطورى كه اين اثر در زمانهايى كه نقدينكى روندزدايىشده در حال افزايش مانى

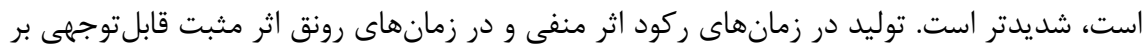

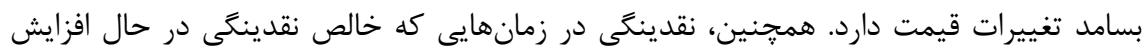

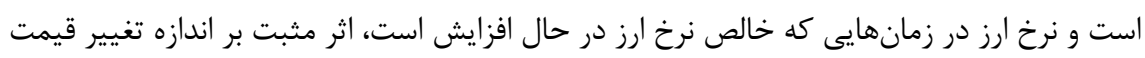

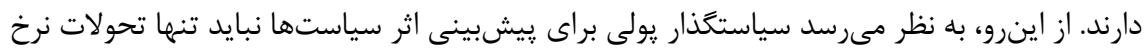
تورم را بررسى كند، بلكه لازم است به تغييرات نقدينكى، توليد، و نرخ ارز نيز توجه ويزهاى داشته

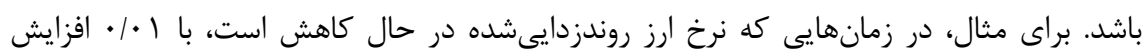

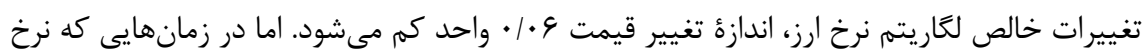
ارز روندزدايىشده در حال افزايش است، با افزايش 1 ••• واحد تغييرات خالص لمَاريتم نرخ ارز، اندازه

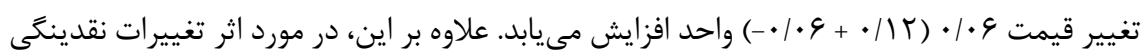
روندزدايىشده مشاهده مىشود در زمانهايى كه خالص نقدينكى در حال كاهش است، با 1 •|

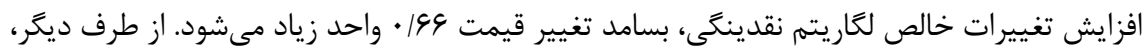
در زمانهايى كه خالص نقدينكى در حال افزايش است، اثر شديدتر مىشود و با افزايش 1 • • • واحد

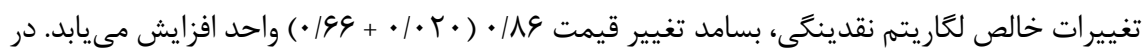

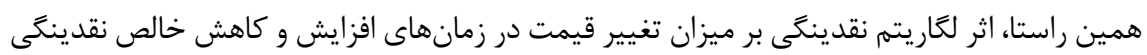

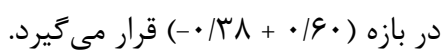
در خصوص توليد نيز مىتوان كفت كه 1 •/• واحد افزايش تغييرات خالص لكاريتم توليد به 9/ 9/ واحد كاهش بسامد تغيير قيمت منجر مىشود، در صورتى كه اين متغير مثبت با همين ميزان

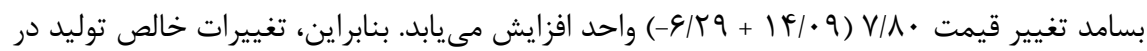
زمانهاى ركود، اثر منفى و در زمانهاى رونق اثر مثبت بر تغييرات بسامد تغيير قيمت دارد. 


\section{مبانى نظرى يزوهش}

قيمتهاى جسبنده يكى از عناصر اصلى سازوكارهاى انتقال در بسيارى از مدلهاى اقتصاد

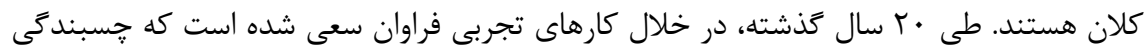

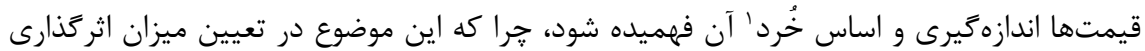
سياستهاى يولى بر وضعيت حقيقى اقتصاد نقش مهمى دارد. طبق مبانى نظرى، سياستهاى يولى

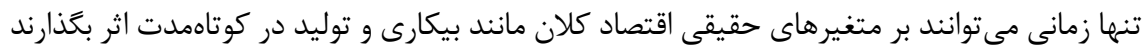
كه قيمتها جسبنده باشند، زيرا در غير اين صورت تمام نوسانات حجم يول روى قيمتها تخليه خواهد شد و افزايش حجم يول تاثيرى بر هيج متغير حقيقى اقتصاد نخواهد داشت. در نخستين يزوهشهايى كه در زمينه سياستهاى يولى و عوامل تاثيرگذار و تاثيريذير از آن نوشته شده، به نظر مىرسد يكى از اهداف اصلى يزوهشكَران كمك به سياستخذاران براى تصميمَّيرى

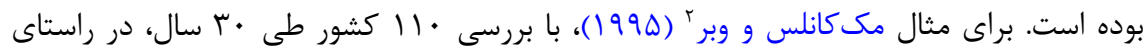

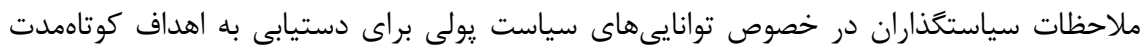

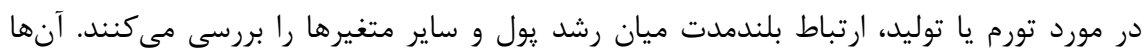
درمىيابند كه بين نرخ رشد عرضه يول و نرخ تورم در بلندمدت، با هر دو نوع تعريف گسترده و محدود

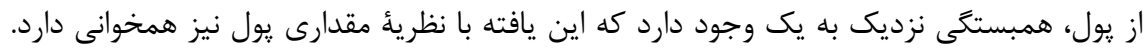

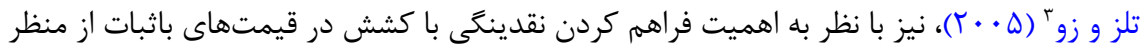

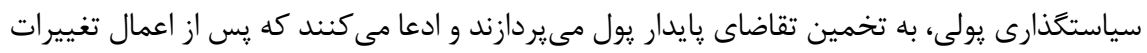

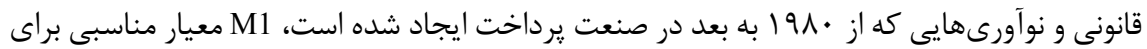
يول نيست و استفاده از MZM باعث مىشود رابطهُ بلندمدت بين يول و هزينهفرصت آن حفظ شود.

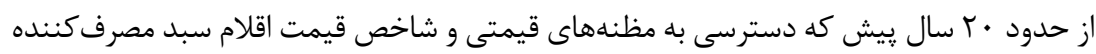

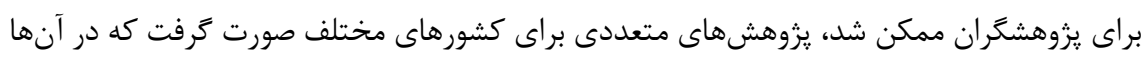

1. Micro Foundation

2. McCandless \& Weber

3. Teles \& Zhou

f. سيردهاى كوتاهمدت و سيردههاى قرضالحسنه كه جزو شبهيول به حساب مى آيند و نهايتاً جزو نقدينكى لحاظ مىشوند، در واقع درست مثل حجم يول عمل مى كنند. بنابراين، در يك تعريف ساده مئوان

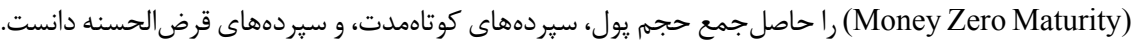




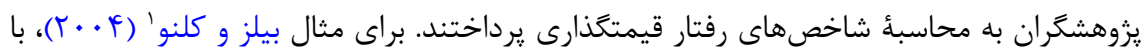

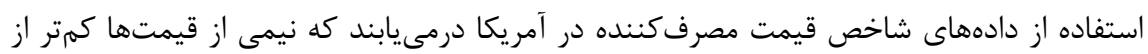

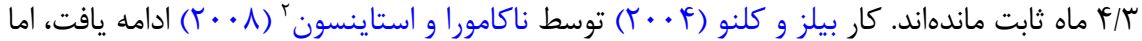

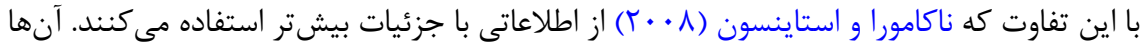

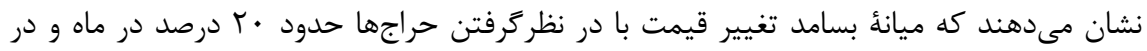

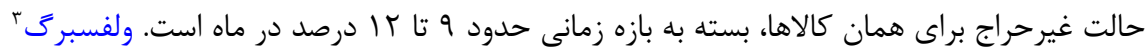

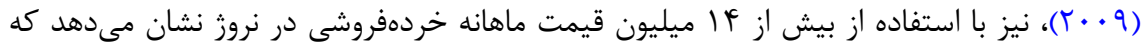

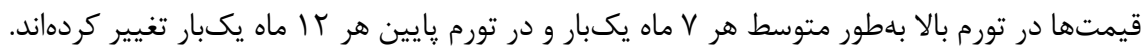

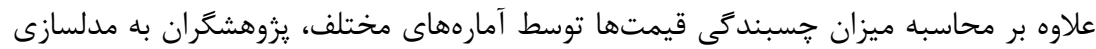
رفتار قيمتگذارى نيز يرداختهاند. امروزه در مبانى نظرى دو دسته مدل براى توضيح رفتار قيمتگذارى وجود دارد: مدل وابسته به زمان ^و مدل وابسته به وضعيته. در مدل وابسته به زمان، تعداد و ميزان تغييرات قيمت متغيرى برونزا و جدا از وضعيت اقتصاد كلان است. ولى در مدل وابسته به وضعيت رفتار قيمتخذارى متغيرى درونزا فرض مىشود كه وابسته به شاخصهاى كلان اقتصادى است و از

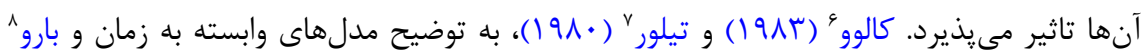

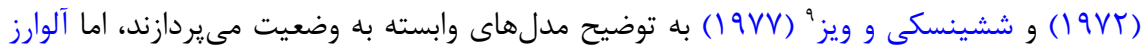

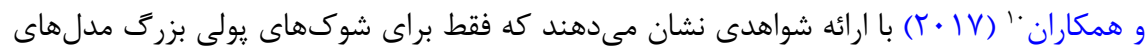

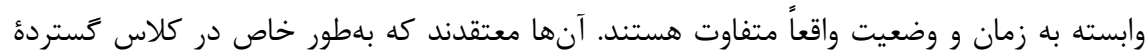

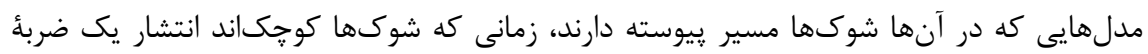
يولى، مستقل از ماهيت اصطكاى قيمت جسبنده است. در عوض، انتشار شوكهاى بزرى به به ماهيت

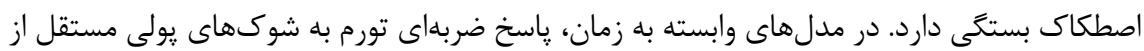

1. Bils \& Klenow

2. Nakamura \& Steinsson

3. Wulfsberg

4. Time-Dependent

5. State-Dependent

6. Calvo

7. Taylor

8. Barro

9. Sheshinski \& Weiss

10. Alvarez et al. 
اندازه شوك است، در حالى كه در مدلهاى وابسته به وضعيت، غيرخطى است.

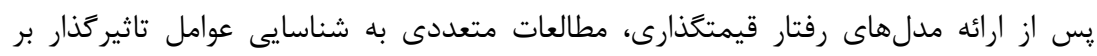

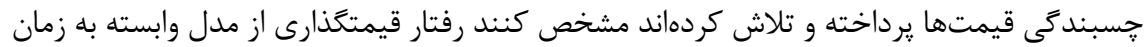
تبعيت مى كند يا از مدل وابسته به وضعيت. براى مثال ناكامورا و استاينسون (1 + •ب)، نشان مى دهند كه بسامد افزايش قيمت براى كشور آمريكا بهشدت با تورم تغيير مى كند، در حالى كه در مورد بسامد

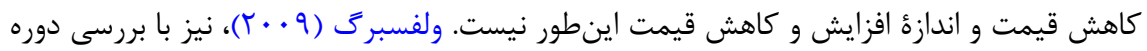

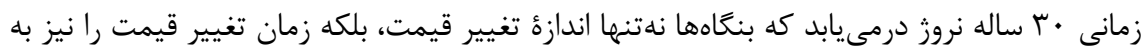

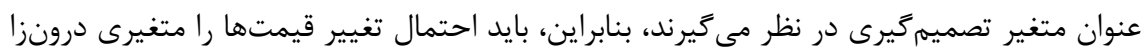
در نظر كرفت كه به وضعيت اقتصاد بستخى دارد. از آنجا كه تغييرات كوجى تورم مانع نتيجه گيرى دقيق در مورد نحوء اثر گذارى تورم بر تغييرات

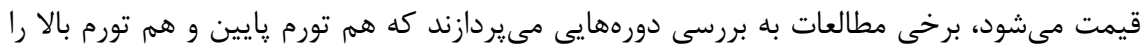

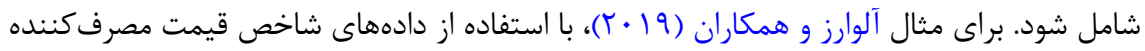

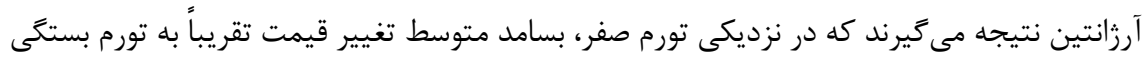

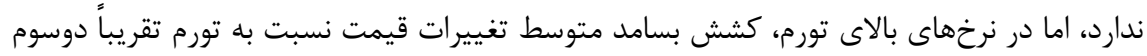

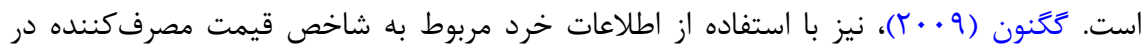

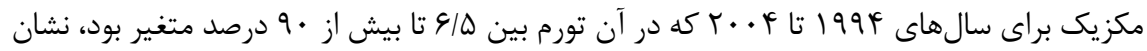

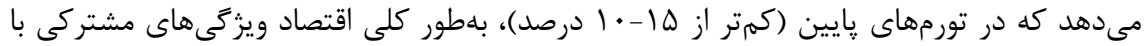

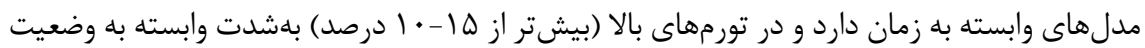
عمل مى كند. يعنى در نرخهاى تورم يايين رابطهاى بين رفتار قيمتخذارى و نرخ تورم وجود ندارد، اما در نرخهاى تورم بالا رابطهاى مثبت و معنادار بين رفتار قيمتخذارى و نرخ تورم مشاهده ميى بورد. در همين راستا براى بررسى رفتار قيمتخذارى در اقتصاد ايران نيز مطالعاتى انجام شده است

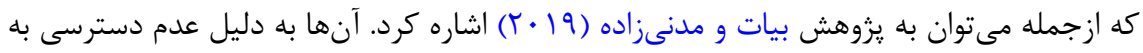
مظنههاى قيمتى از اطلاعات زيراجزاى شاخص قيمت مصرف كننده در بازه زمانى سب ساله از فروردين

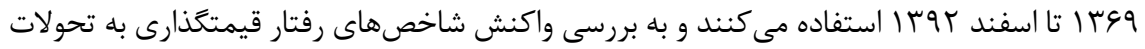
نرخ تورم مى يردازند، و نشان مى دهند كه رفتار اقلام قيمتگذارىشده توسط دولت اولاً نسبت به تورم

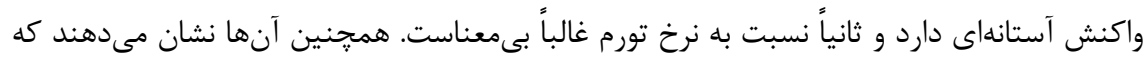

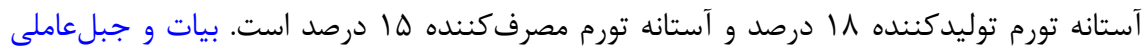


(9 (1)، مطالعه مزبور را يك قدم ييش مىبرند و علاوه بر نرخ تورم، وضعيت رونق و ركود و رزيم

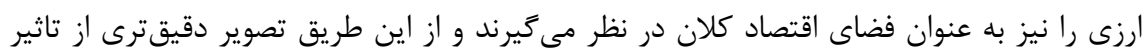

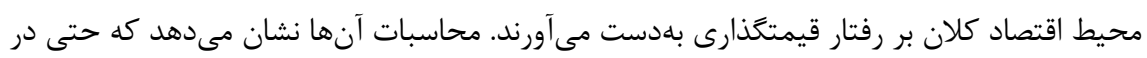

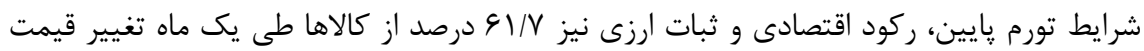

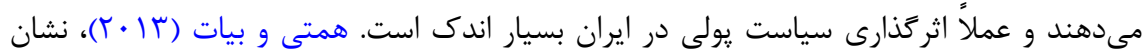
مىدهند كه ماهانه VD درصد از قيمت كالاهاى موجود در سبد خانوار تغيير مى كنيند. صيقلانى و

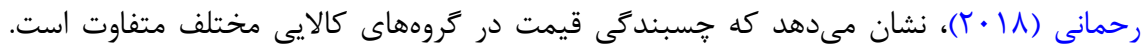

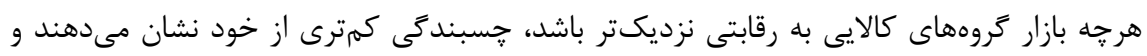

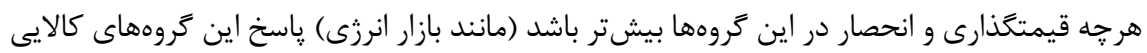

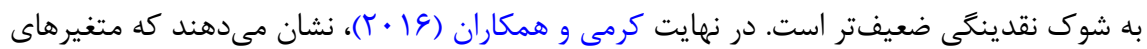

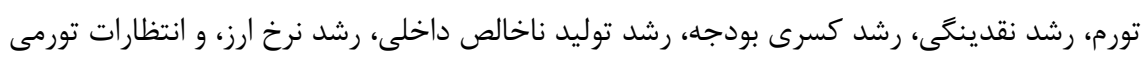

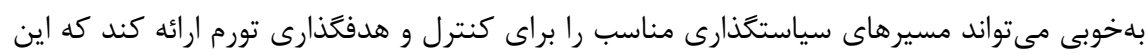

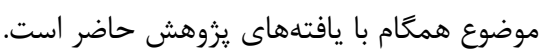
نظر به اهميت فراوان موضوع جسبندگى قيمتها در حوزه سياستخذارى يولى، اين يزوهش قصد دارد به اين يرسشها ياسخ دهد: ميزان جسبندگى قيمت (متوسط بسامد تغييرات قيمت) كالاهاى

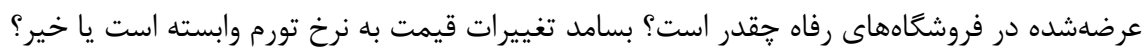

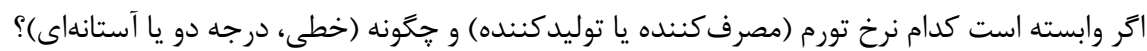

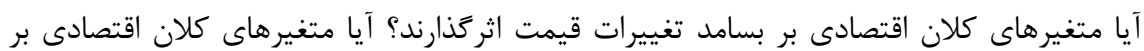

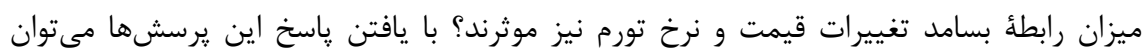

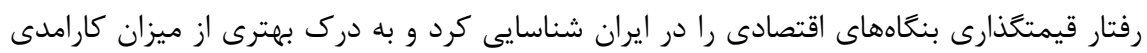
سياستهاى :ولى در اقتصاد ايران دست يافت. جدول (1)، خلاصهاى از برخى مطالعات بيشين انجامشده را در زمينهُ موضوع جسبندگى قيمتها ارائه مى كند. 


\begin{tabular}{|c|c|c|c|c|c|}
\hline نتايج & قيمتى & (خردهروشى) & بازه زمانى & زئه يزوهش & منبع \\
\hline دوره ماند Fارى قيمتها: س/ & * & & $199 \Delta-r \cdots r$ & ايالات & $\begin{array}{c}\text { Bils \& Klenow } \\
\text { (2004) }\end{array}$ \\
\hline هركانس افزايش قيمت بهشدت است با تورم & * & & $1991-r \cdots \Delta$ & متحده & $\begin{array}{l}\text { Nakamura } \\
\text { \& Steinsson } \\
\text { (2008) }\end{array}$ \\
\hline 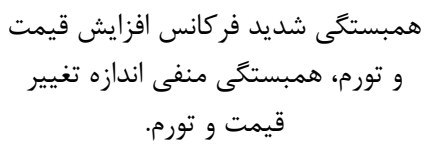 & & * & $19 V \cdot-r \cdot r f$ & ن ن & $\begin{array}{c}\text { Wulfsberg } \\
\text { (2009) }\end{array}$ \\
\hline 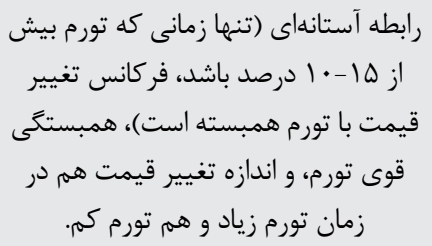 & * & & $1994-r \ldots r$ & مكزيك & Gagnon (2009) \\
\hline ناهمبستخى فر كانس تغيير قيمت با تورم & * & & $1911-199 \mathrm{~V}$ & آرزانتين & $\begin{array}{l}\text { Alvarez et al. } \\
\qquad(2017)\end{array}$ \\
\hline رفتار قيمتخذارى در نرخهاى تورم زياد و & $*$ & & $199 \cdot-r \cdot 1 r$ & ايران & $\begin{array}{c}\text { Bayat \& } \\
\text { Madanizadeh } \\
\text { (2019) }\end{array}$ \\
\hline
\end{tabular}

\section{روش رشناسى يزوهش}

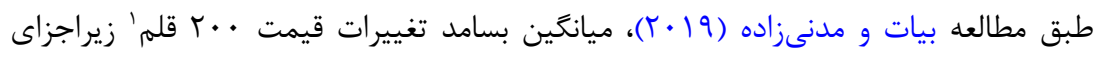

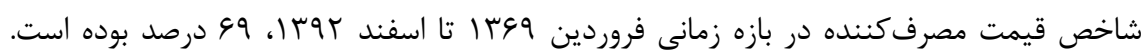

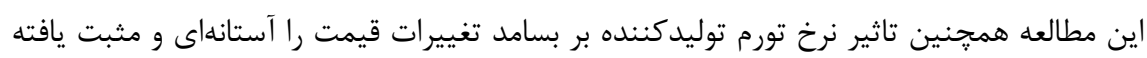

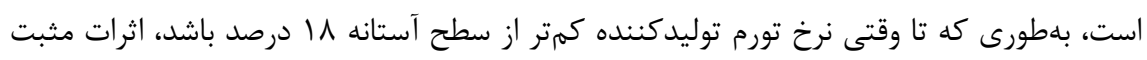

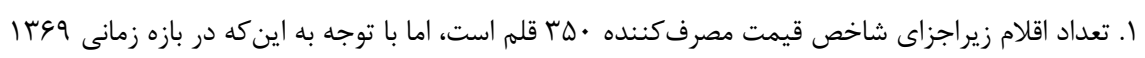

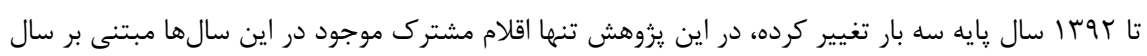


نرخ تورم توليدكننده قوىتر از زمانى است كه نرخ تورم توليدكننده بيشتر از سطح آستانه \ل درصد

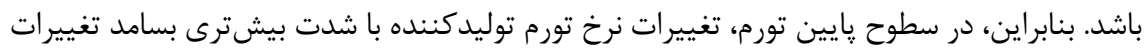

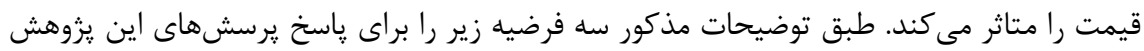

$$
\text { مطرح مى كنيه. }
$$

: ميزان جسبندكى قيمت كالاهاى عرضهشله در فروشكاهماى رفاه بيث /ز • له درصل و دوره ماندكارى قيمت الما حلدود دو ماه /ست. :H2 بسامد تغيير/ت قيمت با نرخ تورم مصرف كننده و توليدكننده رابطه آستانهاى دارد.

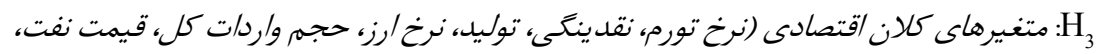

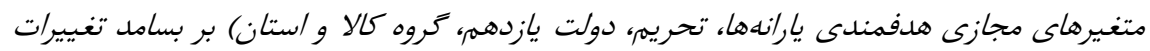

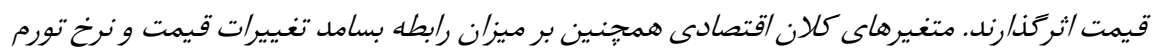
نسيز موثرند. براى بررسى اين فرضيهها از مدلهاى ارائهشده در بخش تصريح مدل استفاده مى كنيم.

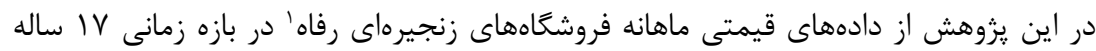

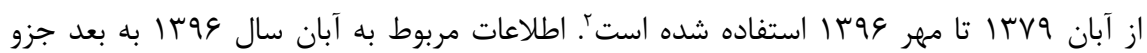
سال مالى جارى شركت محسوب مىشود و به دليل محرمانه بودن قابلدسترسى نيست. شركت فروشگاههاى زنجيرهاى رفاه يكى از گستردهترين شبكههاى توزيع كالا در ايران است كه از ارديبهشت سال عVF

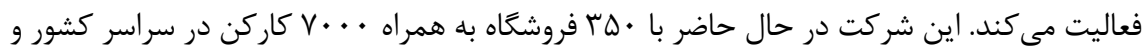
با مشاركت بيش از ·rr شركت توليدى و تامين كننده در حال خدمترسانى به خانوادههاى ايرانى

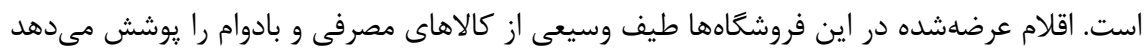
كه مى توان آنها را در شش كروه مواد غذايى و آشاميدنى، مواد غذايى تازه، بهداشتى و و آرايشى، لوازم خانكى و صنعتى سبك، لوازم تحرير ادارى فرهنكى، يوشاك و منسوجات دستهبندى كرد.

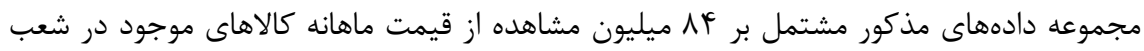

1. https://refah.ir 
سراسر كشور اين فروشكاه است و به تفكيك استان و شعبه قابلدسترسى است. در طى اين IV سال

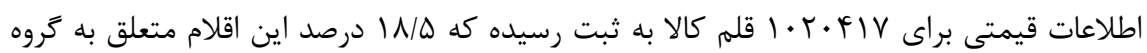

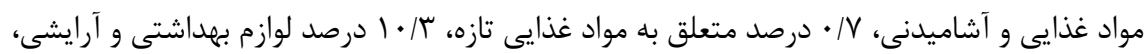

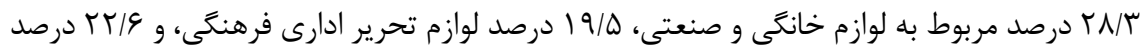
يوشاك و منسوجات بوده است. علاوه بر دادهاى مذكور، از اطلاعات مربوط به برخى متغيرهاى كلان

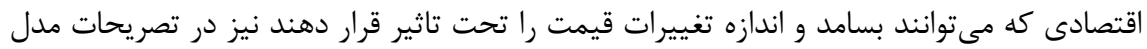
ركرسيون استفاده شده است. اين متغيرها عبارتاند از نرخ تورم ماهانه و نقطهبهنقطه شاخص قيمت بحت توليدكننده، نرخ تورم ماهانه و نقطهبهنقطه شاخص قيمت مصرفكننده، نقدينكى، نرخ ارز، حجم كل واردات، قيمت نفت و توليد. تمامى اين اطلاعات از سايت بانك مركزى جمهورى اسلامى ايران' استخراج شده است.

\section{شاخصهاى رفتار قيمتخذارى}

در اقتصاد براى توصيف رفتار قيمتخذارى بنكاهها، سه آماره اصلى وجود دارد كه عبارتاند از

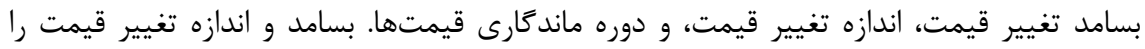
مى توان به بسامد و اندازه افزايش و كاهش قيمت نيز تفكيك كرد. در ادامه به تعريف و نحوه محاسبه

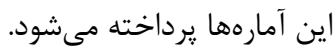

ابتدا شاخص تغيير قيمت هر كالا كه نشاندهنده تغيير يا عدم تغيير قيمت كالا نسبت به ماه قبل

است، به صورت رابطه (1) تعريف مىشود كه در آن $I_{i j t}=\left\{\begin{array}{lll}. & \text { if } & p_{i j t}=p_{i j t-1} \\ 1 & \text { if } & p_{i j t} \neq p_{i j t-1}\end{array}\right.$

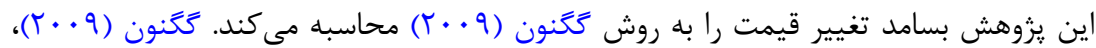
بسامد تغييرات قيمت در هر ماه را به صورت نسبت تعداد كالاهاى تغييرقيمت يافته در آن ماه به تعداد كل كالاها تعريف مى كند. از آنجايى كه دادههاى قيمتى مورد استفاده در اين : يزوهش به به تفكيكى

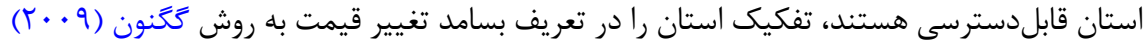
طبق رابطه (r) لحاظ مى كنيم. 
$f_{j t}=\frac{\sum_{i=1}^{n} I_{i j t}}{n_{j t}} * 1 \ldots$

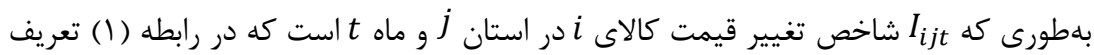

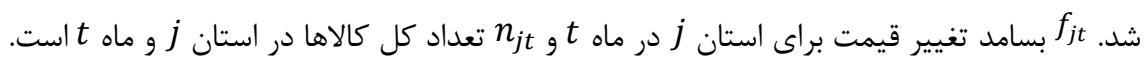

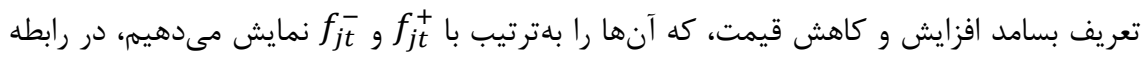

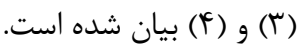

$f_{j t}^{+}=\frac{\sum_{i=1}^{n} I_{i j t}^{+}}{n_{j t}} * 1 \ldots$

$f_{j t}^{-}=\frac{\sum_{i=1}^{n} I_{i j t}^{-}}{n_{j t}} * 1 \ldots$

كه در آنها

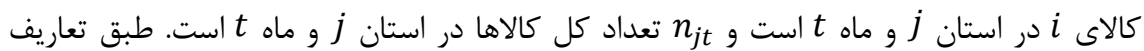

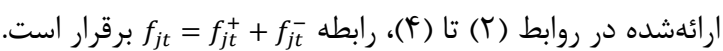

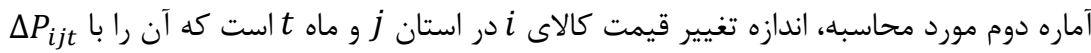

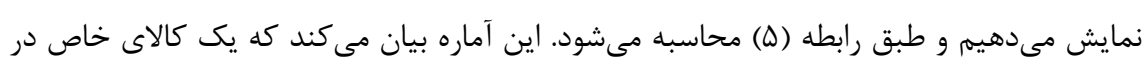
ماه مورد نظر بهطور متوسط حه ميزان (قدر مطلق) تغيير قيمت داشته است.

$\Delta P_{i j t}=\frac{\frac{P_{i j t}-P_{i j(t-\Delta t)}}{P_{i j(t-\Delta t)}}}{\Delta t} * 1 .$.

كه در آن

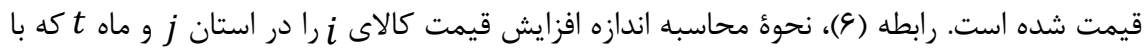

$\Delta P_{i j t}^{+}=\frac{\frac{\Delta P_{i j(t-\Delta t), t}^{+}}{P_{i j(t-\Delta t)}}}{\Delta t} * 1 .$. Dمايش مى دهيم، نشان مىدهد.

همانند اندازه افزايش قيمت، اندازه كاهش قيمت را نيز توسط رابطه (V) محاسبه مى كنيم. $\Delta P_{i j t}^{-}=\frac{\frac{\Delta P_{i j(t-\Delta t), t}^{-}}{P_{i j(t-\Delta t)}}}{\Delta t} * 1 .$. 
آماره ديكرى كه در بررسى رفتار قيمتخذارى بايد محاسبه شود، دوره ماندكارى قيمتهاست. اين

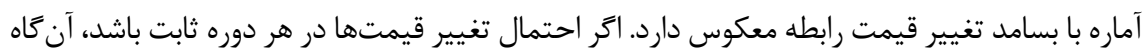

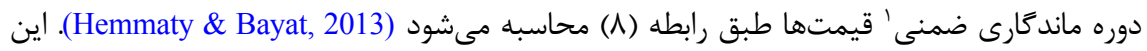
آماره بيان مى كند كه كالاى أ در استان ز و ماه t جه مدات زمان زمان (برحسب ماه) ثابت مانده است. $I D_{j t}=\frac{-1 \cdots}{\ln \left(1-f_{j t} / 1 \cdots\right)}$

كه در آن ft اما اگر فرض كنيم كه تغيير قيمتها حداكثر يكبار در ماه بهوقوع مىييوندد، ماندگًارى

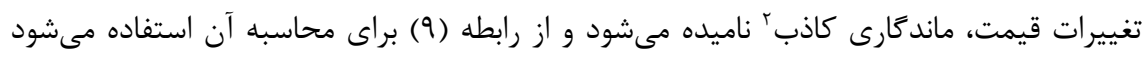
$P D_{j t}=\frac{1 \cdots}{f_{j t}}$

.(Hemmaty \& Bayat, 2013) كه در آن fit

\section{خلاصه آمارى داده}

در اين بخش ابتدا آمارههاى مربوط به رفتار قيمتخذارى يعنى بسامد تغيير، اندازه تغيير، و

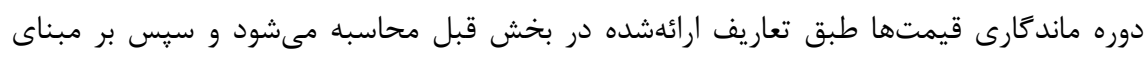

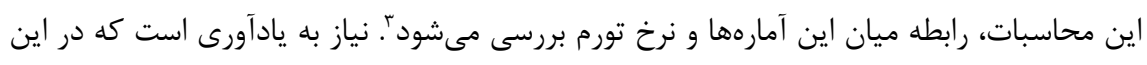
محاسبات براى "اتغييره قيمت تعاريف متفاوتى مىتوان در نظر كرفت. در محاسبات اين يزوهش

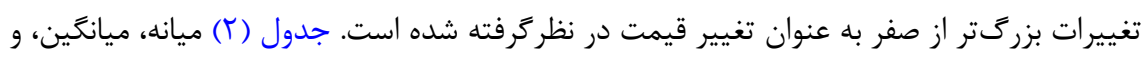

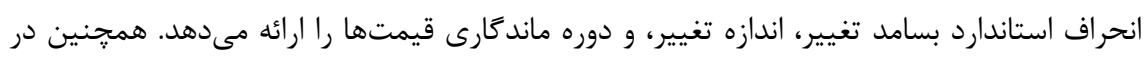
اين جدول، آمارهها به تفكيك افزايش و كاهش قيمت كزارش شدهاند.

\section{Implied Duration}


جدول ז: خلاصه آمارى از داده

\begin{tabular}{|c|c|c|c|c|}
\hline مشاهده & استاندارد انحراف & 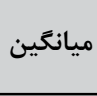 & 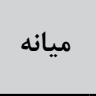 & \\
\hline$\Delta \Delta F \wedge$ & $r Y / 4)$ & $F V / T Y F$ & $\Delta r / r \Delta$ & 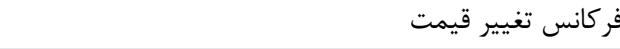 \\
\hline$\Delta \Delta F \wedge$ & $r \cdot / F V$ & $r q / 14$ & $r \cdot / \Delta \Delta$ & فر كانس افزايش قيمت \\
\hline$\Delta \Delta F \wedge$ & $r \cdot / 11$ & IN/Tr & N/IT & 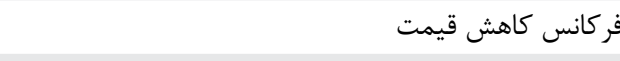 \\
\hline$\Delta \Delta F \wedge$ & $r / T V$ & $\mu / \cdot \Lambda$ & I/AV & 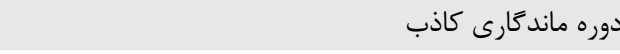 \\
\hline$\Delta Q F \wedge$ & $r / \mathcal{F} \cdot$ & $T / \Delta T$ & $1 / \pi 1$ & 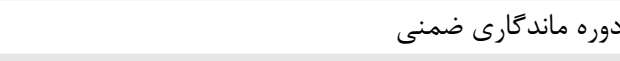 \\
\hline- & $11 / 9$ & 99 & $V \backslash / \mathbb{F}^{4}$ & 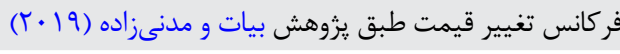 \\
\hline$V V V \cdot \Delta V \wedge$ & $\mid r / T \wedge$ & $1 / \wedge \Lambda$ &.$/ 99$ & ندازه تغيير قيمت \\
\hline FVITTKF & $|f /| r$ & $\Delta / 9 \Delta$ & $r / l r$ & 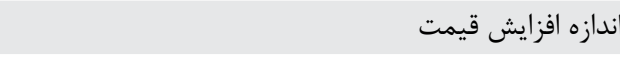 \\
\hline$r \cdot \Delta \wedge r \Delta r$ & $F / F V$ & $r / 9 \mu$ & r/צV & ن ازازه قيمت \\
\hline
\end{tabular}

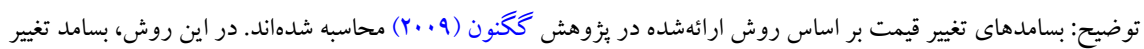

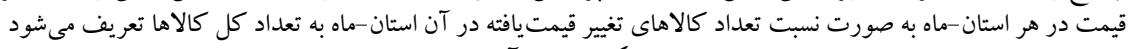

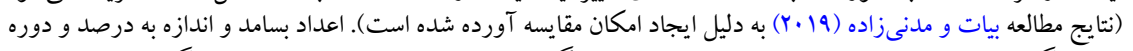

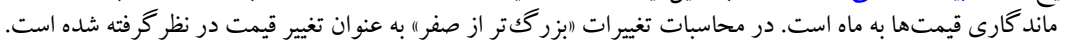

نتايج محاسبات ارائهشده در جدول (Y) نشان مىدهد ميانگين بسامد تغيير قيمت برابر با FV/TKF درصد است. اين بدان معناست كه در هر ماه بلهور متوسط قيمت FV/TK درصد از كل كالاها تغيير كرده است. همجنين در اين جدول مشاهده مىشود كه ميانگين بسامد افزايش قيمت نسبت به ميانگين بسامد كاهش قيمت بيشتر است، كه اين بيشتر بودن با نتايج بلهدستآمده در ساير كشورها ساز

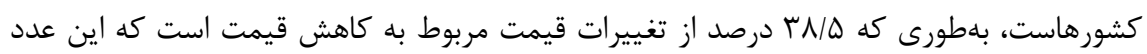

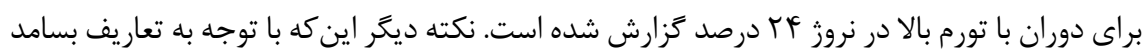

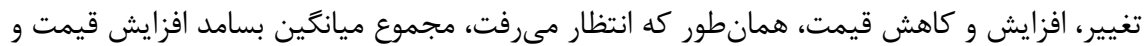
ميانگين بسامد كاهش قيمت برابر با ميانگين بسامد تغيير قيمت است.

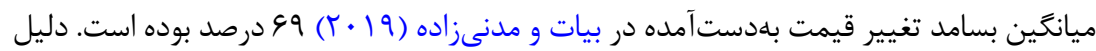

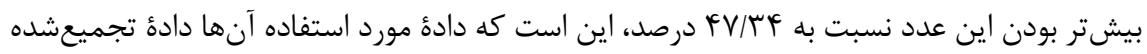

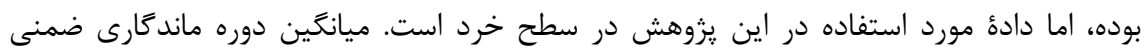




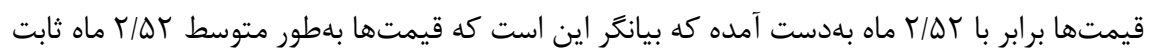

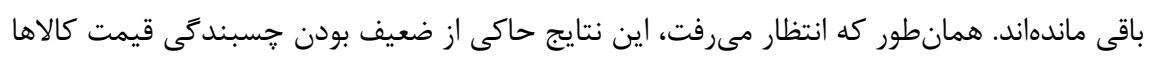

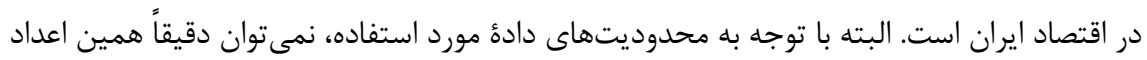

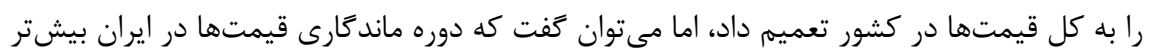
از اعداد كزارششده براى قيمتهاى فروشَاه رفاه نيست.
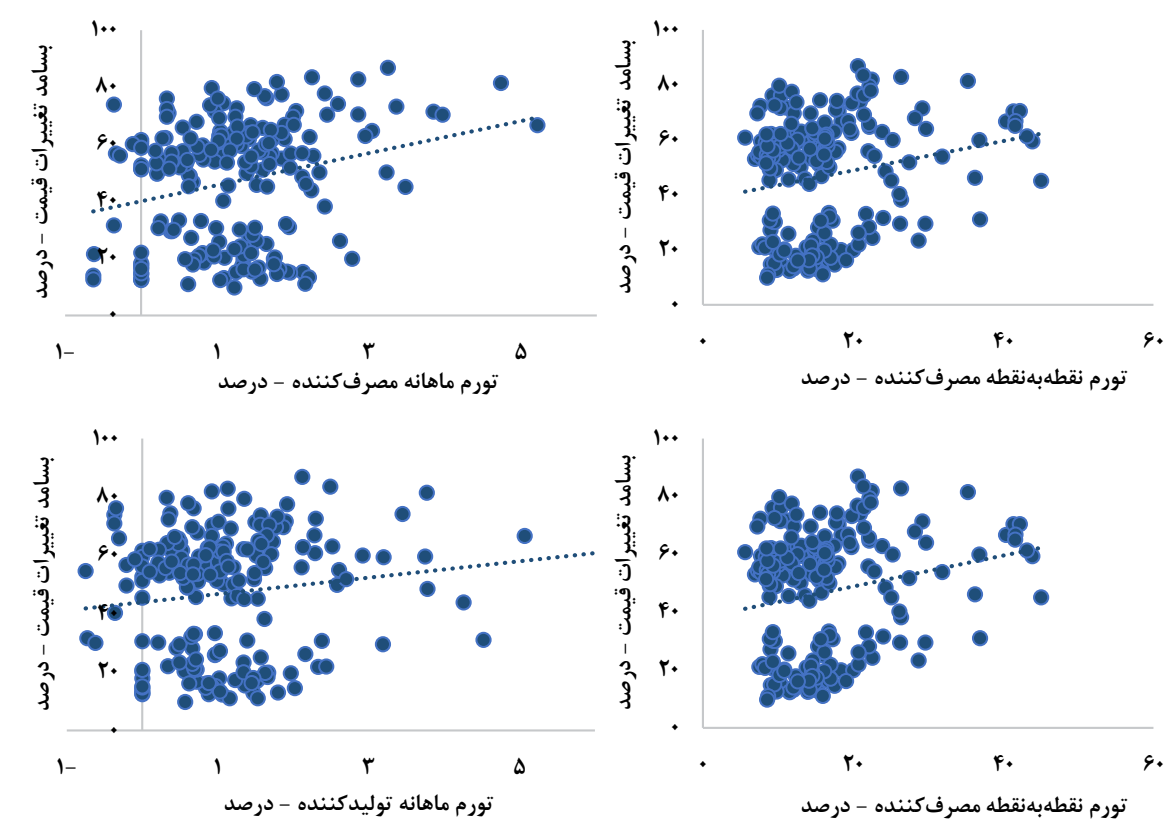

شكل ا: بسامد تنييرات قيمت (محور عمودى) و تورم (محور افقى)

انتظار مىرود كه در ابتداى امر و حتى بدون در نظركرفتن ساير متغيرهاى توضيحى لازم، بين

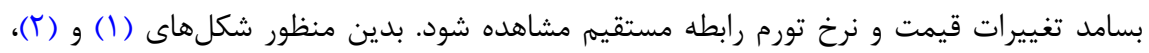

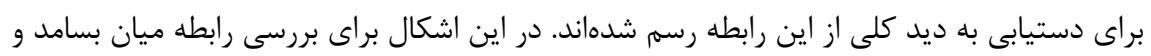

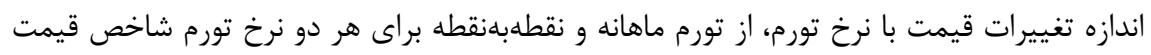
مصرفكننده و شاخص قيمت توليدكننده استفاده شده است. شكل (1)، رابطه بين بسامد تغيير 
قيمت و نرخهاى تورم و شكل (r)، رابطه بين اندازه تغييرات قيمت و نرخ تورم را نمايش ميىدهد.

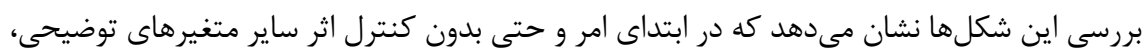

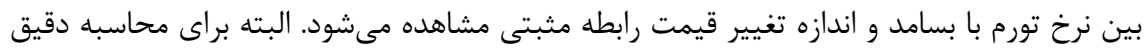
ميزان و جهت اثركذارى نرخ تورم بر بسامد و اندازه تغيير قيمت، لازم است اثر تمامى عوامل موثر

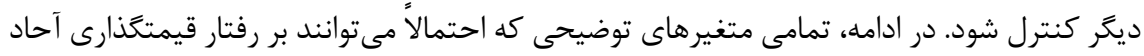

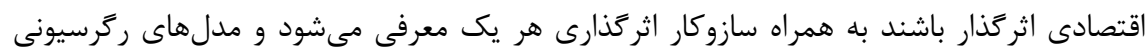
مناسب براى تخمين ميزان اثركذارى آنها شرح داده مىشود.

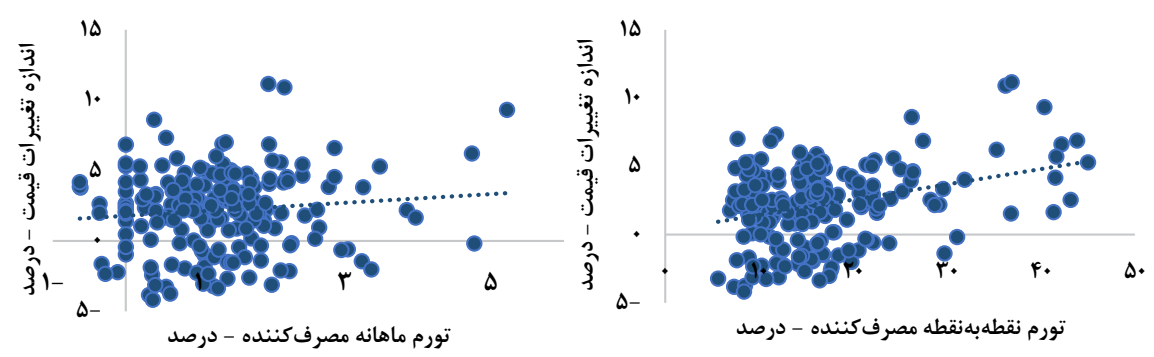




\section{تصريح مدل}

\section{العَوهاى ركرسيونى}

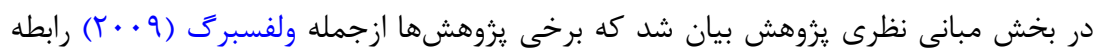

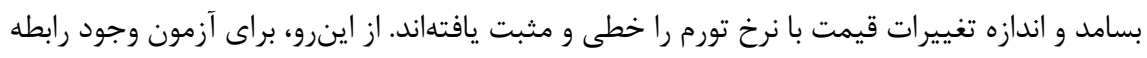

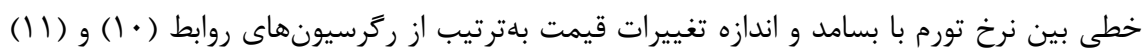

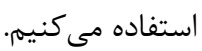

$$
f_{j t}=\alpha+\beta \pi_{t}+\boldsymbol{\gamma} \boldsymbol{X}_{j t}+\boldsymbol{\delta} \boldsymbol{X}_{t}^{\prime}+\boldsymbol{\delta}^{\prime} \boldsymbol{X}_{t}^{\prime} \boldsymbol{Z}_{\boldsymbol{t}}+\epsilon_{j t}
$$

$m_{i j t}=\alpha+\beta \pi_{t}+\boldsymbol{\gamma} \boldsymbol{X}_{\boldsymbol{i j t}}+\boldsymbol{\delta} \boldsymbol{X}_{\boldsymbol{t}}^{\prime}+\boldsymbol{\delta}^{\prime} \boldsymbol{X}_{\boldsymbol{t}}^{\prime} \boldsymbol{Z}_{\boldsymbol{t}}+\epsilon_{i j t}$

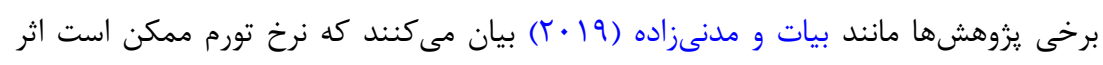

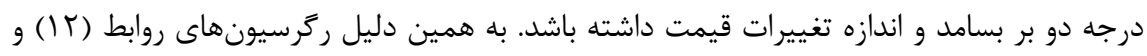
(ז ا ) براى آزمون وجود رابطه درجه دوم بين نرخ تورم بهترتيب با بسامد و اندازه تغييرات قيمت ارائه

$f_{j t}=\alpha+\beta \pi_{t}+\beta^{\prime} \pi_{t}^{r}+\boldsymbol{\gamma} \boldsymbol{X}_{j t}+\boldsymbol{\delta} \boldsymbol{X}_{t}^{\prime}+\boldsymbol{\delta}^{\prime} \boldsymbol{X}_{t}^{\prime} \boldsymbol{Z}_{t}+\epsilon_{j t}$

$m_{i j t}=\alpha+\beta \pi_{t}+\beta^{\prime} \pi_{t}^{r}+\boldsymbol{\gamma} \boldsymbol{X}_{i j t}+\boldsymbol{\delta} \boldsymbol{X}_{t}^{\prime}+\boldsymbol{\delta}^{\prime} \boldsymbol{X}_{t}^{\prime} \boldsymbol{Z}_{\boldsymbol{t}}+\epsilon_{i j t}$

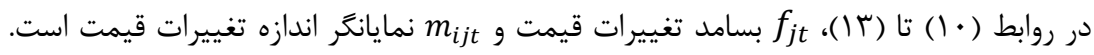

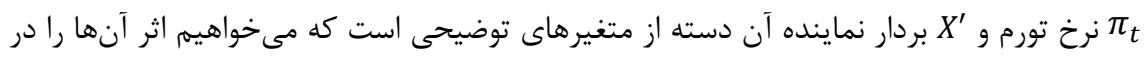

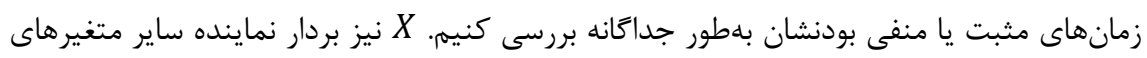
توضيحى مدل است كه در بخش متغيرهاى توضيحى مدل توضيح داده مىشود. t

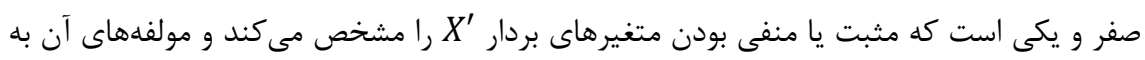
$z_{t}=\left\{\begin{array}{lll}\cdot & \text { if } & x_{t}^{\prime}<. \\ 1 & \text { if } & x_{t}^{\prime} \geq .\end{array}\right.$ صورت رابطه (F) أ ) تعريف مىشود.

يكى ديكر از فرضيههاى مطرح، وجود رابطه آستانهاى بسامد و اندازه تغييرات قيمت با نرخ تورم

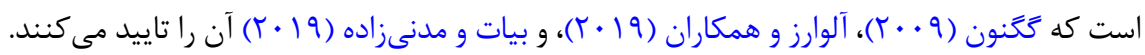

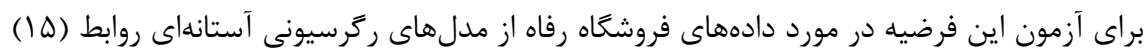


و (19) استفاده مى كنيم.' (19)

$f_{j t}=\left(\alpha .+\beta . \pi_{t}\right) I\left(\pi_{t}, \pi^{*}\right)+\left(\alpha_{1}+\beta, \pi_{t}\right) I\left(\pi_{t}, \pi^{*}\right)+\boldsymbol{\gamma} \boldsymbol{X}_{\boldsymbol{j} \boldsymbol{t}}+\boldsymbol{\delta} \boldsymbol{X}_{\boldsymbol{t}}^{\prime}+\boldsymbol{\delta}^{\prime} \boldsymbol{X}_{\boldsymbol{t}}^{\prime} \boldsymbol{Z}_{\boldsymbol{t}}+\epsilon_{j t} \quad$ (।Q) $m_{i j t}=\left(\alpha .+\beta . \pi_{t}\right) I\left(\pi_{t}, \pi^{*}\right)+\left(\alpha_{1}+\beta, \pi_{t}\right) I\left(\pi_{t}, \pi^{*}\right)+\gamma \boldsymbol{X}_{i j \boldsymbol{t}}+\boldsymbol{\delta} \boldsymbol{X}_{\boldsymbol{t}}^{\prime}+\boldsymbol{\delta}^{\prime} \boldsymbol{X}_{\boldsymbol{t}}^{\prime} \boldsymbol{Z}_{\boldsymbol{t}}+\epsilon_{i j t}(1 \varepsilon)$

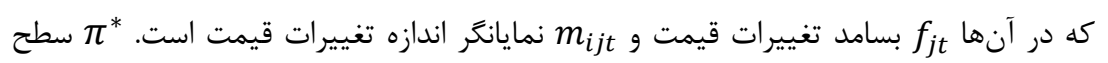

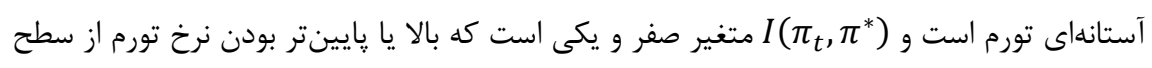

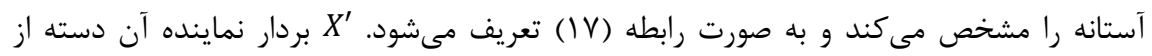
متغيرهاى توضيحى است كه مىخواهيم اثر آنها را در زمانهاى مثبت يا منفى بودنشان بلهُ منور

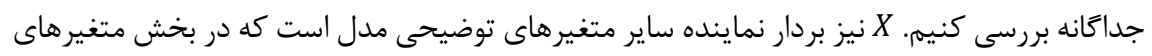

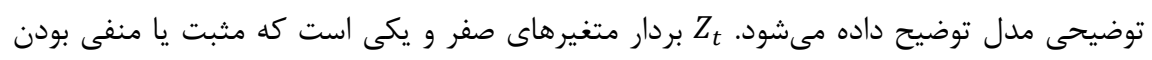

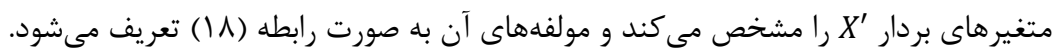
$I\left(\pi_{t}, \pi^{*}\right)=\left\{\begin{array}{lll}\cdot & \text { if } & \pi_{t}<\pi^{*} \\ 1 & \text { if } & \pi_{t} \geq \pi^{*}\end{array}\right.$

$z_{t}=\left\{\begin{array}{lll}\cdot & \text { if } & x_{t}^{\prime}<. \\ 1 & \text { if } & x_{t}^{\prime} \geq .\end{array}\right.$

بر اساس فرضيههاى مطرحشده، انتظار مىرود اجراى تصريحات مذكور، رابطه آستانهاى متغيرهاى

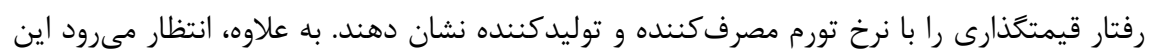

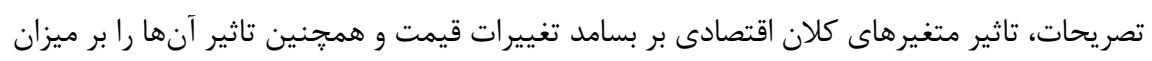
رابطه بسامد تغييرات قيمت و نرخ تورم آشكار سازد.

\section{متغير هاى توضيحى مدل}

اين بخش به معرفى ساير متغيرهاى توضيحى (علاوه بر نرخ تورم) و تبيين دليل انتخاب آنهاو اين كه

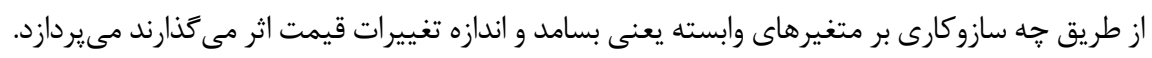

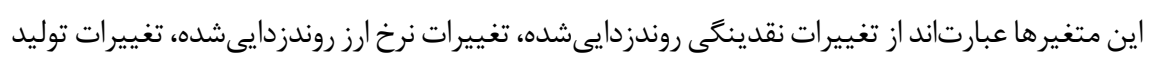

ا. يكسانسازى عرض از مبدأ خط ركرسيون در نقطه آستانه به روش بيات و مدنىزاده (19 • (1) انجام شده 
روندزدايىشده، لكاريتم حجم واردات كل، رشد قيمت نفت، متغير مجازى هدفمندى يارانهها، متغير مجازى تحريمها، متغير مجازى دولت يازدهم، متغير مجازى گروه كالا، و متغير مجازى استان.

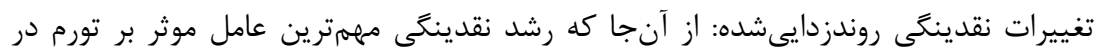
بلندمدت است، افزايش آن مىتواند سيحنالى براى افزايش نرخ تورم در آينده باشد، زيرا در هنَّام

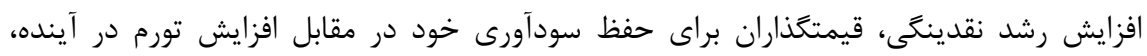
قيمتهايشان را با تصميمگيرى درباره بسامد و اندازه تغييرات قيمت تعديل مىكنيند. علاوه بر

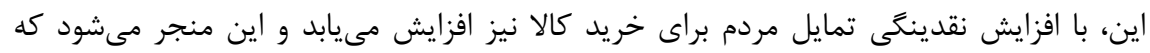
فروشندكان تقاضاى بيشترى را احساس كنند و در نتيجه، قيمتهايشان را تعديل نمايند. براى

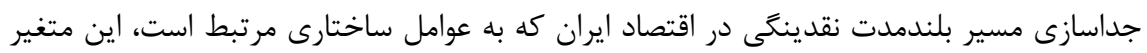

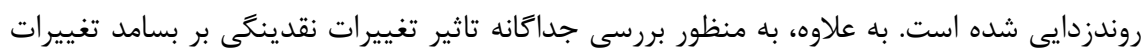

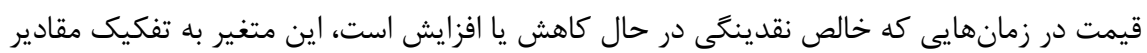
مثبت و منفى در مدل لحاظ شده است. تغييرات توليد روندزدايىشده: تحولات رشد توليد نمايانگر دوران ركود يا رونق در اقتصاد كشور است. در يى افزايش رشد توليد يا همان يررونق شدن شرايط اقتصادى كشور، معاملات انجامشده در

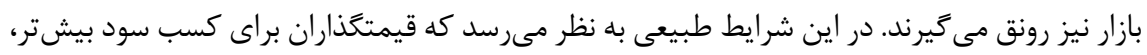

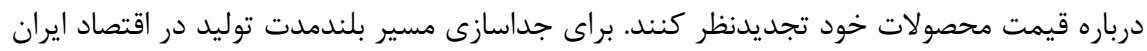

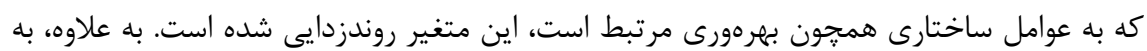

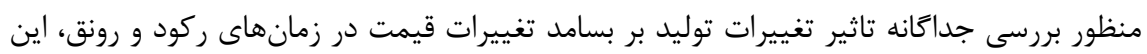
متغير به تفكيك مقادير مثبت و منفى در مدل لحاظ شده است.

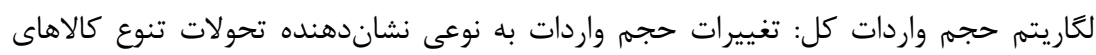

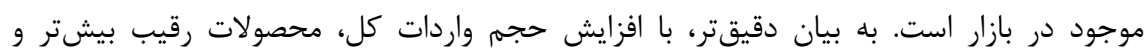

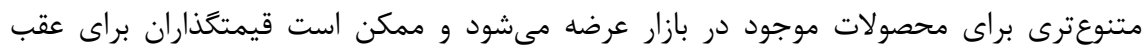

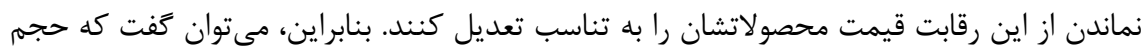

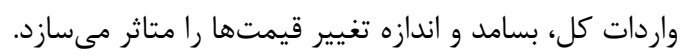
تغييرات نرخ ارز روندزدايىشده: نرخ ارز، لنگر انتظارات تورمى مردم در ايران است. افزايش نرخ

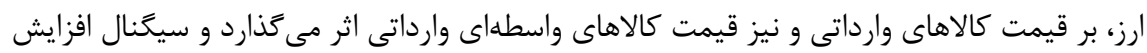

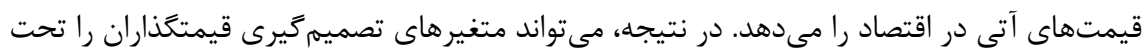


تاثير قرار دهد. براى جداسازى مسير بلندمدت نرخ ارز در اقتصاد ايران كه به عوامل ساختارى مرتبط

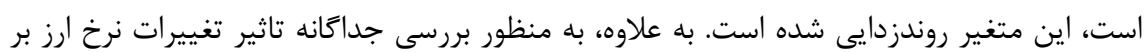

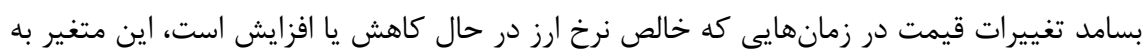
تفكيك مقادير مثبت و منفى در مدل لحاظ شده است. رشد قيمت نفت: رشد قيمت نفت از كانال تامين مالى كسرى بودجه دولت بر نرخ تورم اثرگذار است. تغييرات نرخ تورم نيز رفتار قيمتخذاران را تحت تاثير قرار مىدهد.

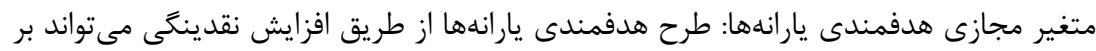

$$
\text { تورم آتى اثر كذار باشد. }
$$

متغير مجازى تحريم: تحريمهاى اقتصادى تحميلشده بر كشور را مى تواند به عنوان شوكى منفى واردشده بر اقتصاد در نظر كرفت كه با كاهش واردات كالاهاى واسطهاى، سيخنال افزايش قيمتهاى آتى در اقتصاد را مى دهد كه اين مىتواند عامل تغيير روال تعديل قيمتها باشد.

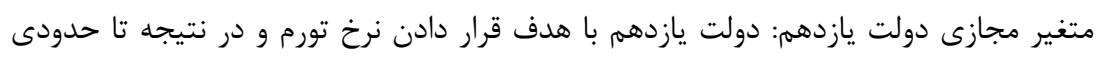

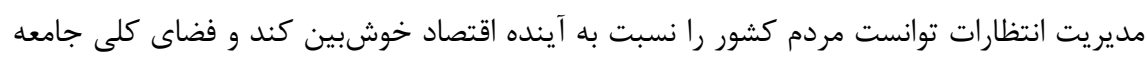
را به سمت آرامش و اطمينان سوق دهد. بدين ترتيب، انتظار مىرود كه در اين دوران رويه قبلى

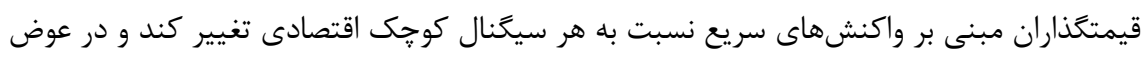

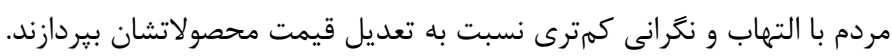

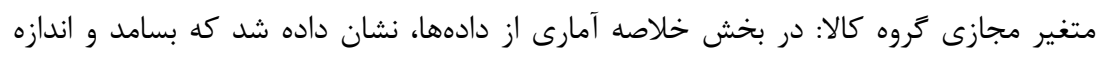

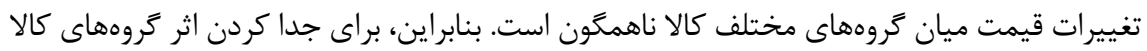
ينج متغير مجازى (براى شش گروه كالا) در نظر كرفته شد.

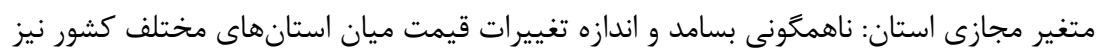

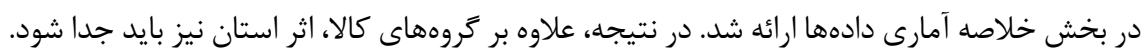
به همين منظور اس متغير مجازى (براى rr استان كشور) در نظركرفته شد.

\section{تجزيهو تحليل يافتهها}

اين بخش به ارائه پاسخ يرسشهاى اين يزوهش كه در بخش مبانى نظرى يروهش بيان شد،

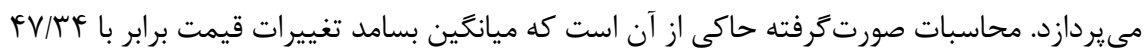

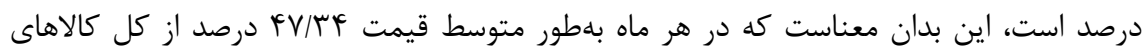


فروشكاههاى رفاه تغيير كرده است. مطابق با نتايج ارائهشده در جدول (ب)، بسامد تغييرات قيمت با نرخهاى تورم مصرفكننده و توليدكننده رابطه آستانهاى مثبت دارد، بهطورى كه با عبور از نرخ تورم آستانه از شدت اين اثر مثبت كاسته مىشود. در ادامه، به جزئيات اين روابط و تحليل كمّى اثرات يرداخته خواهد شد.

\section{نتايج مربوط به بسامد تغييرات قيمت}

جدول (ץ)، تصريحات ركرسيون بسامد تغييرات قيمت بر نرخ تورم و ساير متغيرهاى توضيحى را ارائه مى دهد'. در اين جدول، در هر تصريح متغيرهاى توضيحى يكبهيك به مدل اضافه شدهاند، زيرا

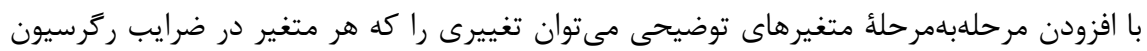
ايجاد مى كند مشاهده كرد. در ستون ا اين جدول (1)، مشاهده مىشود كه بدون كنترل هيج متغير ديگرى، رابطه آستانهاى بين بسامد تغيير قيمت و تورم نقطهبهنقطه توليدكننده وجود دارد، بهطورى

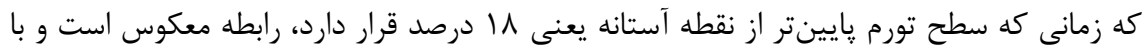
افزايش يك واحد تورم، بسامد تغيير قيمت بهطور ميانگين ه/1/ • واحد كاهش مىيابد. اما زمانى كه تورم بالاى \| درصد است، رابطه مستقيم است و با افزايش يك واحد تورم، بسامد تغيير قيمت بهطور

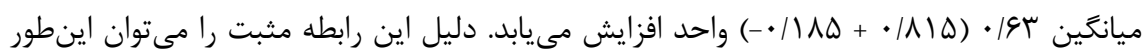
توضيح داد كه افزايش نرخ تورم توليدكننده سيكنالى از افزايش قيمت مصرفكنينده در آينده است. در واقع انتظار مىرود با افزايش قيمت نهادههاى توليد قيمت نهايى كالاها نيز افزايش يابد. بنابراين، هرجه تورم توليدكننده بيشتر باشد، تعداد تغيير قيمت كالاهاى نهايى نيز براى يوشش هزئ هزينه توليد بيشتر خواهد شد. در ستون T جدول (rا)، متغير تغييرات نقدينكى روندزدايىشده به تفكيك زمانهايى كه اين متغير مثبت يا منفى است (يعنى بلهترتيب در زمانهاى افزايش يا كاهش خالص نقدينكى) به مدل

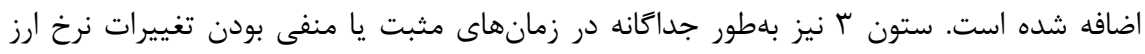

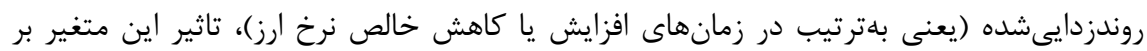
بسامد تغيير قيمت را شامل مىشود. مشاهده مىشود كه با اضافه كردن اين دو متغير، ضريب تورم

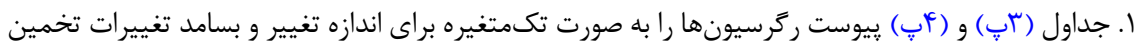

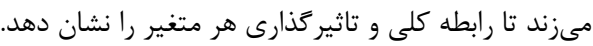


در زمانهايى كه تورم بالاتر از سطح آستانه قرار دارد، همجنان مثبت است اما AV • • • واحد نسبت به ستون ا كمرتر شده است. در ستون 9 جدول (rا)، با قرار دادن تمام متغيرهاى توضيحى در مدل، اثر هر يك از آنها در كنار حضور متغيرهاى ديكر بررسى شده است. در اين تصريح مشاهده مىشود كه بين نرخ تورم و بسامد تغيير قيمت، هم قبل و هم بعد از آستانه نرخ تورم رابطه مستقيم برقرار است، اما شدت اين رابطه بعد از آستانه كمتر مىشود، بهطورى كه افزايش يكى واحد تورم نقطهبهنقطه توليدكنينده با ثبات تمام

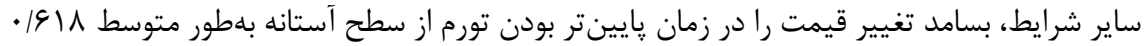

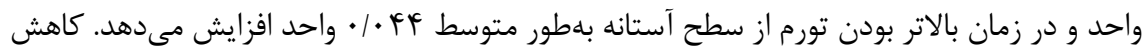
شدت اثر مستقيم تورم بر بسامد تغيير قيمت را مىتوان اينطور توضيح داد كه زمانى كه تورم از سطح

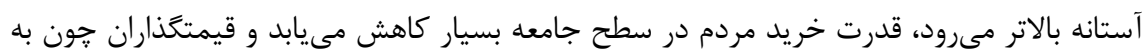
اين واقعيت واقفند كمتر از زمانهاى تورم پايين، قيمت كالاهايشان را تغيير مى دهند.

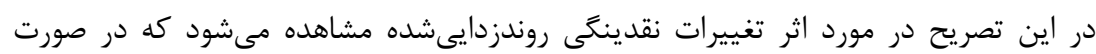

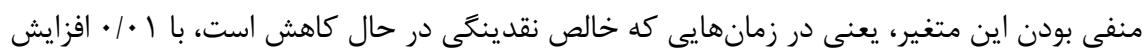
تغييرات خالص لكَاريتم نقدينكَى، بسامد تغيير قيمت 191. واحد زياد مىشود. از طرف ديكر، در صورتى كه اين متغير مثبت باشد، يعنى در زمانهايى كه خالص نقدينكى در حال افزايش است، اثر

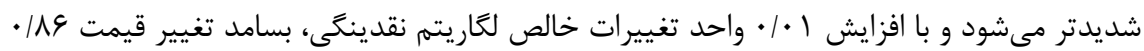

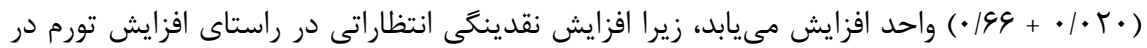

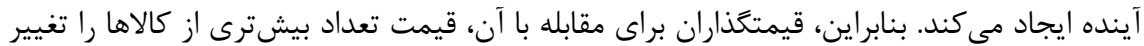
مى مهند و بسامد تغيير قيمت افزايش ميى يابد. در مورد تغييرات توليد روندزدايىشده مشاهده مىشود، زمانى كه اين متغير منفى است، يعنى در درد

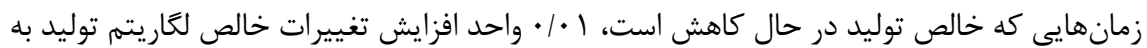
9/ و واحد كاهش بسامد تغيير قيمت منجر مىشود، اما در صورتى كه اين متغير مثبت باشد، يعنى در زمانهايى كه خالص توليد در حال افزايش است، با افزايش 1 •/• واحد تغييرات خالص لكَاريتم

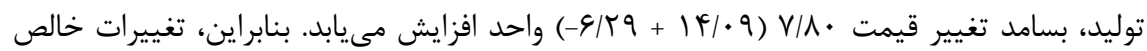
توليد در زمانهاى ركود، اثر منفى و در زمانهاى رونق اثر مثبت بر تغييرات بسامد تغيير قيمت دارد.

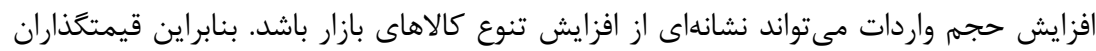

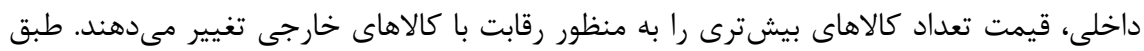


ستون 9 جدول (Y)، يك درصد افزايش حجم واردات، بسامد تغيير قيمت را بهطور متوسط IFFF واحد افزايش مى دهد. اجراى طرح هدفمندى يارانهها از كانال افزايش تورم انتظارى بر بسامد تغيير قيمتها اثر دارد، زيرا با اجراى اين طرح مردم اين سيحنال را دريافت مى كنند كه اين امر در آينده باعث افزايش نرخ

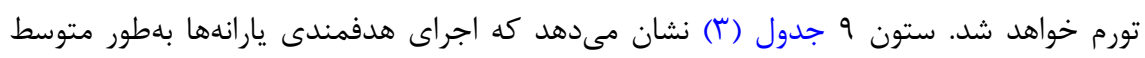
N/9VD واحد افزايش بسامد تغيير قيمت رادر يى دارد. همجنين، با اعمال تحريمها و در صورت ثبات

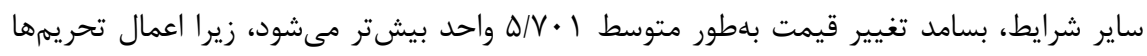
شوك منفى براى اقتصاد تلقى مىشود و با ايجاد التهاب و نكرانى در ميان آحاد اقتصادى، انتظار

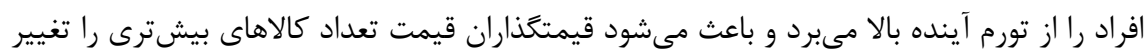

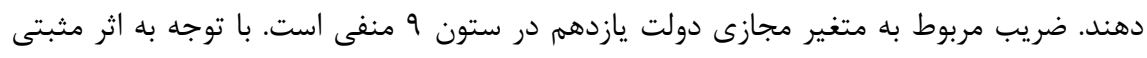

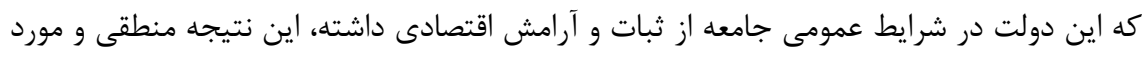
انتظار است. 
جدول "ا: نتايج ركرسيون بسامد تغييرات قيمت بر متغيرهاى توضيحى

\begin{tabular}{|c|c|c|c|c|c|c|c|c|c|}
\hline (9) & $(\Lambda)$ & $(\vee)$ & (9) & $(\Delta)$ & $(f)$ & (广) & ( $(\mathbf{T})$ & (1) & \\
\hline 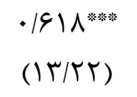 & 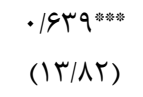 & 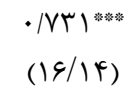 & 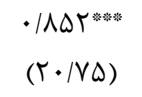 & 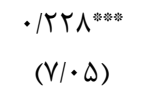 & $\begin{array}{l}\cdot / \cdot V \Delta \varphi^{*} \\
(Y / G Y)\end{array}$ & $\begin{array}{l}-\cdot / Y \Gamma \Lambda^{* * w^{*}} \\
(-V / V V)\end{array}$ & 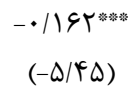 & 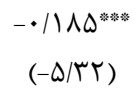 & تورم نقطهبهنقطه توليدكننده \\
\hline $\begin{array}{l}-\cdot \mid \Delta V f^{c * * * a s} \\
(-|r / \Delta|)\end{array}$ & $\begin{array}{c}-\cdot / \Gamma Y^{\mathcal{F}^{* * * * *}} \\
(-\Lambda / q \cdot)\end{array}$ & $\begin{array}{l}-\cdot / f f f^{* * * * *} \\
(-11 / \cdot 1)\end{array}$ & 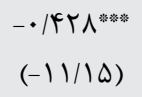 & $\begin{array}{l}\cdot / T G \cdot * * * * \\
(V / 9 \cdot)\end{array}$ & 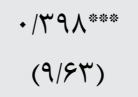 & $\begin{array}{l}\cdot|\mathrm{V} \wedge|^{* * * * *} \\
(\mid \mathrm{V} / \cdot \Delta)\end{array}$ & $\begin{array}{l}\cdot \mid \wedge F \Psi^{* * * *} \\
(\mid \vee / \Gamma q)\end{array}$ & $\begin{array}{l}\cdot|\Lambda| Q^{* * *} \\
(\mid \Delta / \vee \Lambda)\end{array}$ & متغير آستانه تورم نقطهبهنقطه \\
\hline 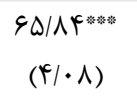 & $\begin{array}{l}\Gamma \varphi / \Delta q^{*} \\
(r / r q)\end{array}$ & $\begin{array}{l}-\Delta / F \mu F \\
(-\cdot / T V)\end{array}$ & $\begin{array}{l}99 / 9 \Upsilon^{w * * *} \\
(\Delta / 1 \wedge)\end{array}$ & 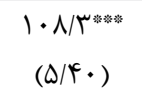 & $\begin{array}{l}M F / T) \\
(1 / \mathcal{G})\end{array}$ & $\begin{array}{l}-\Delta \wedge \Delta / \cdot{ }^{*} *{ }^{*} \\
(-\mid \vee / V \vee)\end{array}$ & $\begin{array}{l}-\Delta r r / 9^{* * * *} \\
(-19 / \mid \Delta)\end{array}$ & & تغييرات نقدينكى روندزدايىشده - \\
\hline $\begin{array}{l}r \cdot / 1 T \\
(\cdot / 1 \cdot)\end{array}$ & $\begin{array}{l}\Delta / / \Lambda \cdot * \\
(Y / \cdot \Lambda)\end{array}$ & $\begin{array}{l}V \& \mid \Lambda F^{F * *} \\
(\Psi / 1 \&)\end{array}$ & $\begin{array}{l}-\Delta Y / \Lambda T \\
(-I / V \Lambda)\end{array}$ & $\begin{array}{l}-1 \wedge \Delta / V^{* * * *} \\
(-\Delta / 9 \Delta)\end{array}$ & $\begin{array}{l}r / / \mathcal{F} . \\
(\cdot / \Lambda \mu)\end{array}$ & $\begin{array}{l}\vee \backslash \Lambda / \Lambda^{* * * *} \\
(\mid Y / V 9)\end{array}$ & $\begin{array}{l}9 \cdot 1 / 9^{* * * *} \\
(11 / 94)\end{array}$ & & تغييرات نقدينگى روندزدا \\
\hline 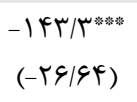 & $\begin{array}{l}-\mid \Delta \mathcal{F} / V^{*} \\
(-Y \cdot / \Delta V)\end{array}$ & $\begin{array}{l}-|9| / 0^{*} \\
(-Y \mid / \cdot r)\end{array}$ & $\begin{array}{l}-199 / 0^{*} \\
(-1 / 19)\end{array}$ & 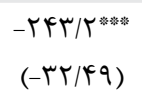 & $\begin{array}{l}-r q \cdot / q^{*} \\
(-r Y / r \wedge)\end{array}$ & 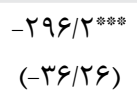 & & & تغييرات نرخ ارز روندزدايىشده - \\
\hline $\begin{array}{l}V / / 9 \Delta^{\text {*w: }} \\
(\mid Y / T \varphi)\end{array}$ & 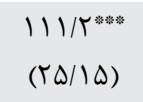 & 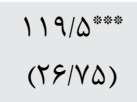 & 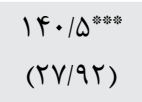 & $\begin{array}{l}r F \Delta / \Delta^{* * * *} \\
(r) / 9 r)\end{array}$ & $\begin{array}{l}r \Psi I^{* * * *} \\
(\Psi V / \Delta \varphi)\end{array}$ & 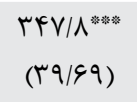 & & & تغييرات نرخ ارز روندزدايىشده + \\
\hline $\begin{array}{l}-G Y \wedge / \Lambda^{*} \text { * } \\
(-Y Y / q Y)\end{array}$ & 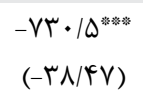 & 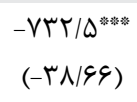 & $\begin{array}{l}-\vee q \vee / \cdot * \text { * } \\
(-Y q / \vee \cdot)\end{array}$ & $\begin{array}{l}-\Lambda \Delta \cdot 1 \cdot \\
(-\mathcal{E} / \Delta \Delta)\end{array}$ & 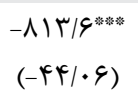 & & & & تغييرات توليد روندزدايىشده - \\
\hline $\begin{array}{l}\mid f \cdot \Lambda / q^{* * *} \\
(\Psi V / \mid F)\end{array}$ & 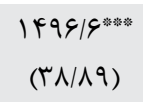 & $\begin{array}{l}|\digamma q| / \Delta^{* * * *} \\
(\Upsilon \wedge / \vee \Delta)\end{array}$ & $\begin{array}{l}109 f / K^{*} \\
(f \cdot / \mid 1)\end{array}$ & 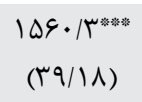 & 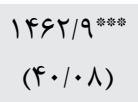 & & & & تغييرات توليد روندزدايىشده + \\
\hline 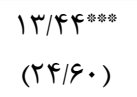 & 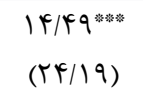 & $\begin{array}{l}19 / 19^{\text {***as }} \\
(Y 9 / 99)\end{array}$ & 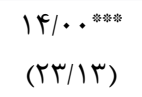 & 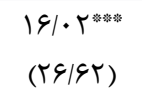 & & & & & حجم واردات \\
\hline 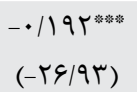 & 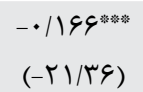 & 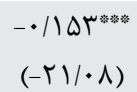 & $\begin{array}{l}-\cdot / T \cdot \Delta^{* * * * a} \\
(-Y \wedge / 9 \Delta)\end{array}$ & & & & & & رشد قيمت نفت \\
\hline
\end{tabular}


ادامه جدول r: نتايج ركرسيون بسامد تغييرات قيمت بر متغيرهاى توضيحى (1)

\begin{tabular}{|c|c|c|c|c|c|c|c|c|c|}
\hline (9) & $(\Lambda)$ & $(\vee)$ & $(9)$ & $(\Delta)$ & $(\boldsymbol{F})$ & $(r)$ & $(r)$ & (1) & \\
\hline 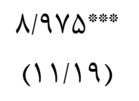 & $\begin{array}{c}r / \cdot \mathcal{F})^{\text {was }} \\
(\mathcal{F} / \Psi \cdot)\end{array}$ & 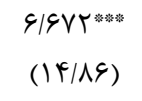 & & & & & & & متغير مجازى هدفمندى يارانهها \\
\hline $\begin{array}{l}\Delta / V \cdot l^{*} \\
(11 / \mathcal{E} Y)\end{array}$ & $\begin{array}{l}\Delta / \Lambda \mid \Gamma^{* * *} \\
(\mid \backslash / \& \uparrow)\end{array}$ & & & & & & & & متغير مجازى تحريم \\
\hline $\begin{array}{l}-9 / 4 r \Delta^{* * * *} \\
(-1 \cdot / 41)\end{array}$ & & & & & & & & & متغير مجازى دولت يازدهم \\
\hline $\begin{array}{l}-\Lambda \Lambda / \Delta \Delta^{* * * *} \\
(-\mid \Lambda / \Lambda \mu)\end{array}$ & $\begin{array}{l}-9 \Lambda / \Gamma^{\mu} \\
(-19 / \cdot \cdot)\end{array}$ & $\begin{array}{l}-\| I / \mathbb{F}^{*} \\
(-r \mid / V \Delta)\end{array}$ & $\begin{array}{l}-q \Psi / \wedge V^{*} \\
(-\mid \vee / \vee \varphi)\end{array}$ & $\begin{array}{l}-1 \cdot \Delta / q^{*} \\
(-19 / \wedge \vee)\end{array}$ & 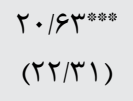 & $\begin{array}{l}\text { r\&/G } \Delta^{*} \\
(r 9 / \Delta 9)\end{array}$ & 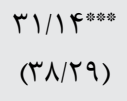 & $\begin{array}{l}M F / V V^{*} \\
(Y \& / I V)\end{array}$ & ثابت \\
\hline rqv^ & rqv^ & rqv^ & rqv^ & rq४^ & 0.19 & $\Delta T \& \Lambda$ & $\Delta T G \Lambda$ & $\Delta \Delta F \wedge$ & تعداد مشاهده \\
\hline - / $\Delta \Delta \varphi$ & $\cdot \mid \Delta F \lambda$ & . IDFT & - $/ \Delta M^{\prime}$ & - IFVG & - $/ F F$. & . & . & . /rqr & $\mathrm{R} 2$ \\
\hline
\end{tabular}

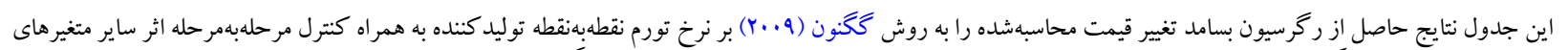

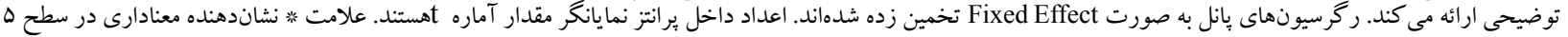
درصد، 


\section{نتايج مربوط به اندازه تغييرات قيمت}

جدول (Y)، تصريحات رگرسيون اندازه تغييرات قيمت را بر نرخ تورم و ساير متغيرهاى توضيحى ارائه مى دهد. در اين جدول نيز، در هر تصريح، متغيرهاى توضيحى يكبديك به مدل اضافه شدهاند، زيرا با افزودن مرحلهبهمرحلهُ متغيرهاى توضيحى مى توان تغييرى را كه هر متغير در ضرايب ركرسيون ايجاد مى كند مشاهده كرد. در ستون ا جدول (4)، مشاهده مىشود كه بدون كنترل ساير شرايط،

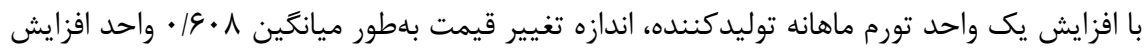

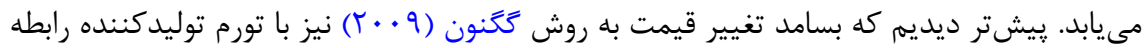

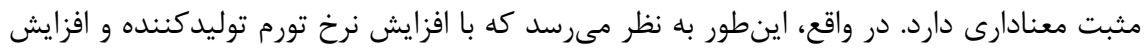

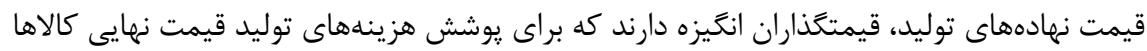
را با اندازه بيشترى نيز تغيير دهند تا سود خود را حفظ كنند. در ستون 9 جدول (f) با قرار دادن تمام متغيرهاى توضيحى در مدل، اثر هر يك از آنها در كنار حضور متغيرهاى ديگر بررسى شده است. در اين تصريح مشاهده مىشود كه افزايش يك واحد تورم

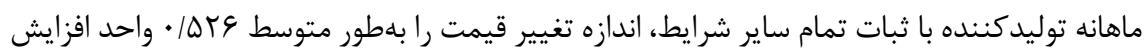
مىدهد. مشاهده مىشود كه ضريب مربوط به نرخ تورم ماهانه توليدكننده از ستون اول (1 • •|• )

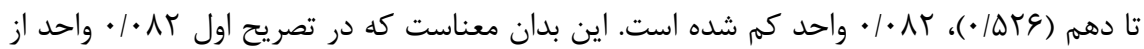
ضريب تورم در اصل مربوط به ساير متغيرهاى كلان اقتصادى است كه تغيير آنها در نهايت موجب

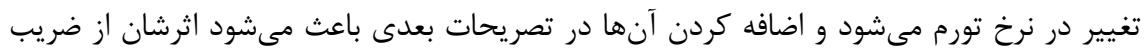
تورم خارج شود و اين ضريب كاهش يابد. در مورد اثر تغييرات نقدينكى روندزايىشده در ستون 9 جدول (أ) مشاهده مىشود كه در صورت

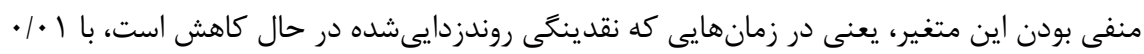

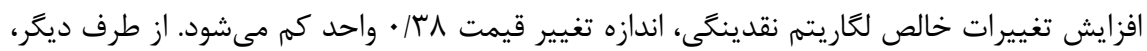
در صورتى كه اين متغير مثبت باشد، يعنى در زمانهايى كه نقدينكى روندزدايىشده در حال افزايش است، اثر اين متغير معكوس مىشود و با افزايش 1 • • • واحد افزايش تغييرات خالص لكاريتم نقدينكىى،

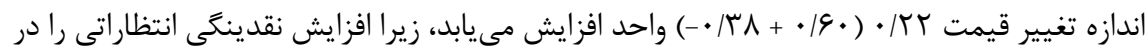

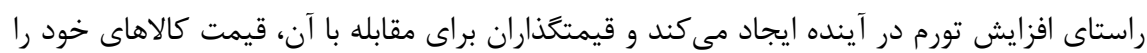


اثر تغييرات نرخ ارز روندزايىشده نيز در ستون 9 جدول (F) مشاهده مىشود. در صورت منفى

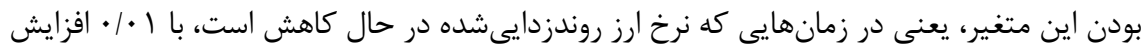

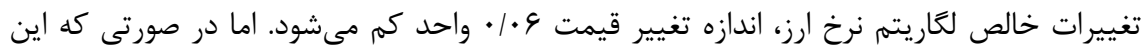
متغير مثبت باشد، يعنى در زمانهايى كه نرخ ارز روندزدايىشده در حال افزايش است، با افزايش ردان

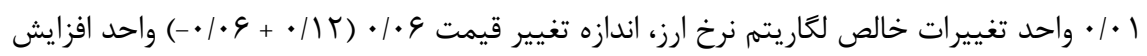
مىيابد، زيرا افزايش نرخ ارز روندزدايىشده نسبت به ماه قبل سيگنالى از افزايش قيمت كالاهاى

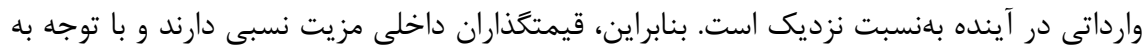

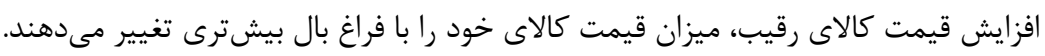

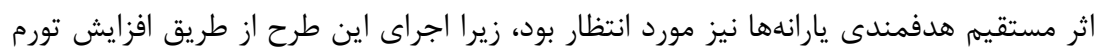

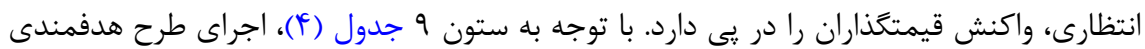
يارانهها بهطور ميانگين باعث ه\&94/ • واحد افزايش اندازه تغيير قيمت مىشود.

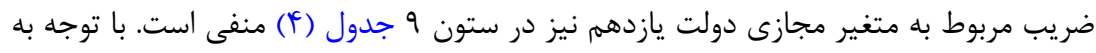

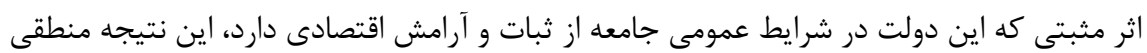
و مورد انتظار است. ثبات و آرامش ايجادشده در سطح جامعه طى اين دولت، باعث مىشود كه قيمتخذاران اندازه تغيير قيمت كالاهاى خود را كاهش دهند. 
جدول †: نتايج ركرسيون اندازه تغييرات قيمت بر متغيرهاى توضيحى

\begin{tabular}{|c|c|c|c|c|c|c|c|c|c|}
\hline (9) & $(\Lambda)$ & (V) & (द) & $(\Delta)$ & $(\boldsymbol{F})$ & (r) & (Y) & (1) & \\
\hline 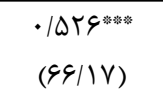 & $\begin{array}{l}\cdot \mid 94 Q^{*} \omega^{* * *} \\
(\vee \wedge / 99)\end{array}$ & 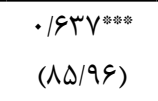 & 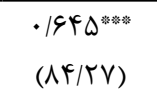 & 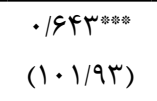 & 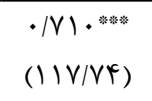 & 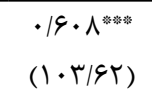 & $\begin{array}{l}.1919^{*} \\
(1.9 / 0 Y)\end{array}$ & 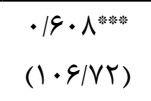 & تورم ماهانه توليدكننده \\
\hline 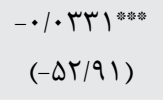 & $\begin{array}{c}-\cdot|\cdot| q \mid \Lambda^{* * *} \\
(-9 \Delta / f \mid)\end{array}$ & $\begin{array}{c}-\cdot|\cdot f| Y^{*}: \\
(-V \cdot / \mid V)\end{array}$ & $\begin{array}{c}-\cdot / \cdot F \mid V^{* * *} \\
(-99 / \wedge F)\end{array}$ & $\begin{array}{c}-\cdot|\cdot F| Q^{* * * w} \\
(-V 9 / Y \mid)\end{array}$ & $\begin{array}{c}-\cdot / \cdot 4 \wedge 9^{* * * *} \\
(-9 \Delta / 9 \Psi)\end{array}$ & $\begin{array}{c}-\cdot / \cdot F Y \Lambda^{* * * a} \\
(-\Lambda \Delta / \Delta \Lambda)\end{array}$ & $\begin{array}{c}-\cdot / \cdot r \Delta \cdot \cdot \vec{*} \\
(-V \Delta / \Delta V)\end{array}$ & 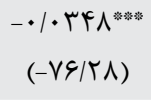 & توليدكننده تورم ماهانه \\
\hline 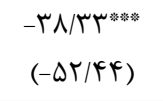 & 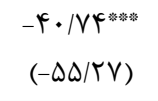 & 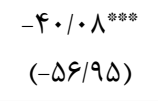 & 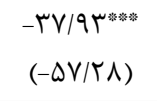 & 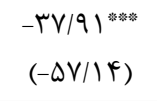 & 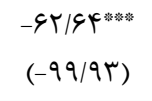 & 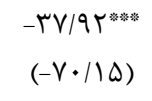 & 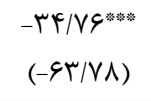 & & روندييرات نقدينكى \\
\hline $\begin{array}{l}9 \cdot / 1 \cdot * * \\
(9 \cdot / 9 \mathrm{~V})\end{array}$ & $\begin{array}{l}\vee \backslash / \Upsilon \Lambda^{* * * *} \\
(\vee \backslash / Y \Lambda)\end{array}$ & $\begin{array}{l}V \cdot / 9)^{\text {**** }} \\
(Y G / V Y)\end{array}$ & $\begin{array}{l}\text { GN/VV**: } \\
(V Y / Y \cdot)\end{array}$ & $\begin{array}{l}\text { GN/G } \\
(Y Y / 9 \mid)\end{array}$ & $\begin{array}{l}\wedge \mathrm{V} / 19^{* * * *} \\
(9 Y / \Lambda \Lambda)\end{array}$ & $\begin{array}{l}99 / \cdot \varphi^{* * * *} \\
(V V / V \cdot)\end{array}$ & $\begin{array}{l}9 / / \Delta \Lambda^{* * *} \\
\left.(V / / \Lambda)^{\prime}\right)\end{array}$ & & 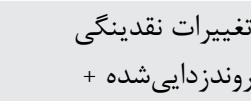 \\
\hline $\begin{array}{l}-G / \Delta \mu V^{*} \\
(-Y \cdot \mid \Delta \Delta)\end{array}$ & $\begin{array}{l}-11 / \Gamma q^{* * * * *} \\
(-\mu \& \mid \cdot \Delta)\end{array}$ & 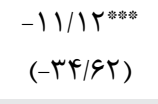 & 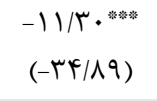 & 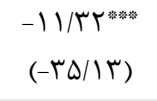 & $\begin{array}{l}-\mid Y / G Y \text { \% } \\
(-F Y / G V)\end{array}$ & $\begin{array}{l}-\mid Y / \Delta \varphi^{* * * * *} \\
(-Y|/ T|)\end{array}$ & & & تغييرات نرخ ارز \\
\hline 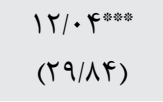 & 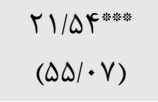 & 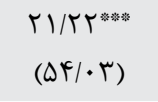 & $\begin{array}{l}r \mid / V Q^{* * * *} \\
(\Delta Y / \Lambda \Lambda)\end{array}$ & 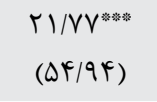 & $\begin{array}{l}r \mid / V 9^{* * \omega^{*}} \\
(\Delta \Delta / Y G)\end{array}$ & $\begin{array}{l}r \cdot / r q^{*} \\
(\Delta r / q 9)\end{array}$ & & & تغييرات نرخ ارز \\
\hline 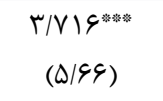 & 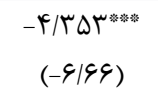 & 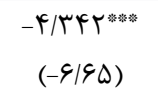 & 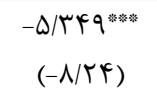 & 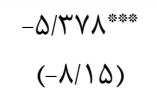 & 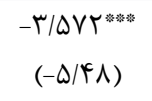 & & & & تغييرات توليد - روندزدايىشده - \\
\hline $\begin{array}{l}-Y Y / \mathcal{C} \cdot * \text { : } \\
(-Y Y / 9 \varphi)\end{array}$ & $\begin{array}{l}-r \varepsilon / \Gamma \Delta^{*} \\
(-r \Delta / ৭ \varphi)\end{array}$ & 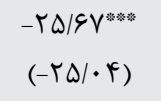 & $\begin{array}{l}-Y \Psi / \cdot \wedge^{* * *: *} \\
(-Y K / V \Delta)\end{array}$ & $\begin{array}{l}-r F / 1 \cdot{ }^{*} \\
(-Y r / 9 T)\end{array}$ & $\begin{array}{l}-r \varphi / T \cdot{ }^{*} \\
(-Y V / \mathcal{H} \cdot)\end{array}$ & & & & روندزدايىشده + \\
\hline 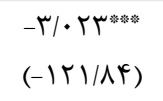 & 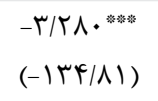 & $\begin{array}{l}-\Gamma / \Gamma \mid \cdot{ }^{*} \\
(-\mid r \Delta / V T)\end{array}$ & 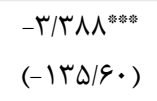 & 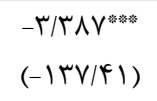 & & & & & لكاريتم حجم واردات \\
\hline $\begin{array}{c}-\cdot / \cdot \Delta \cdot 1^{* *} \\
(-19 / 1 \cdot)\end{array}$ & $\begin{array}{c}\cdot 1 \cdots \Delta q \Lambda^{*} \\
(Y / \Delta F)\end{array}$ & $\begin{array}{c}\cdot / \cdots \cdot \Delta \cdot \Delta \\
(\cdot / 19)\end{array}$ & $\begin{array}{c}-\cdot \cdot \cdot \cdot r r r \\
(-\cdot / \Lambda F)\end{array}$ & & & & & & رشد قيمت نفت \\
\hline
\end{tabular}




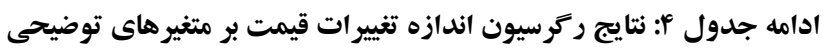

\begin{tabular}{|c|c|c|c|c|c|c|c|c|c|}
\hline (9) & (^) & $(\vee)$ & (9) & $(\Delta)$ & $(\boldsymbol{F})$ & $(\Psi)$ & $(r)$ & (1) & \\
\hline $\begin{array}{l}\cdot / 9 Y Q^{* * * * *} \\
(Y q / T /)\end{array}$ & 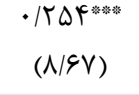 & 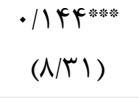 & & & & & & & متغير مجازى هدفمندى \\
\hline $\begin{array}{c}-\cdot / T \cdot{ }^{* * * *} \\
(-V / T r)\end{array}$ & $\begin{array}{c}-\cdot / 1 \Delta \cdot \cdots \\
(-\Delta / \Delta \cdot)\end{array}$ & & & & & & & & متغير مجازى تحريم \\
\hline $\begin{array}{l}-1 /\left.\Delta \Delta\right|^{* * *} \\
(-\Lambda 1 / \cdot 1)\end{array}$ & & & & & & & & & متغير مجازى دولت يازدهم \\
\hline $\begin{array}{l}Y Y / \Lambda Y^{* *: 0} \\
(\mid Y Y / / \Lambda)\end{array}$ & 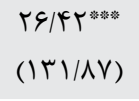 & $\begin{array}{l}r \& / G D^{* *: *} \\
(I T Y / V q)\end{array}$ & $\begin{array}{l}r V / r \Delta^{* * \omega *} \\
(I r \Delta / V \Delta)\end{array}$ & $\begin{array}{l}r V / T \Delta^{* * * *} \\
(\mid r G / 9 \Lambda)\end{array}$ & $\begin{array}{l}-\cdot / \cdot f r r \\
(-1 / A I)\end{array}$ & $\begin{array}{l}\cdot / r \wedge 9^{* * * a s} \\
(\mid r / 4 q)\end{array}$ & 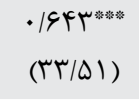 & $\begin{array}{l}1 / 19)^{* * * a} \\
(99 / 01)\end{array}$ & ثابت \\
\hline 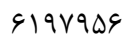 & $919 \vee 908$ & द) १४१०द & 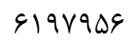 & 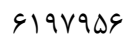 & GMNTITA & VHYqIFV & VHTqIFV & $V V V \cdot \Delta V \Lambda$ & تعداد مشاهده \\
\hline$\cdot / \cdot r \wedge$ & . I. TV & • $/ \mathrm{TV}$ & / $/ T V$ & - / TV & $\cdot / \cdot r \Delta$ & $\cdot / \cdot$ Ts & /. rद & •/.TV & R2 \\
\hline
\end{tabular}

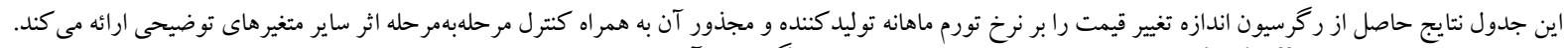

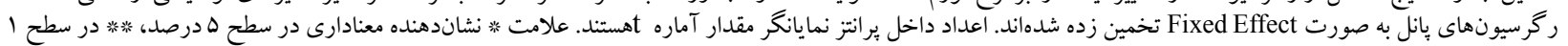

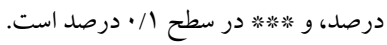




\section{آزمون هاى بايدارى نتايج}

جداول (ه) و (9)، يايدارى نتايج ارائهشده در بخش قبل را نسبت به نرخ تورمهاى مختلف، يعنى نقان

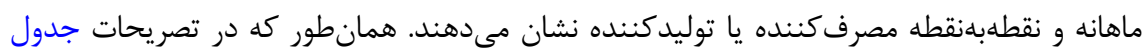
(ه) مشاهده مىشود، بسامد تغيير قيمت با همه نرخ تورمهاى ماهانه و نقطلبهنقطه مصرفكننده و توليدكننده رابطه مستقيم آستانهاى دارد، باططورى كه شدت اثركذارى بعد از آستانه كاهش مى يابد. به علاوه، رابطه مثبت توليد با بسامد تغيير قيمت در زمانهاى رونق و رابطه منفى آنها در زمانهاي

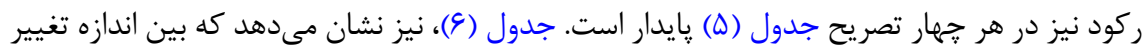
قيمت و همه نرخ تورمهاى ماهانه و نقطهبهنقطه مصرفكننده و توليدكننده رابطهُ مستقيم برقرار

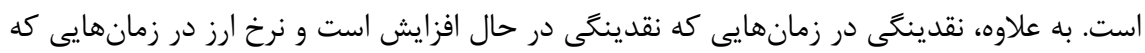
نرخ ارز در حال افزايش است، در هر جهار تصريح اثر مثبت معنادارى بر اندازه تغيير قيمت دانئ دارند. 


\begin{tabular}{|c|c|c|c|c|}
\hline \multicolumn{5}{|c|}{ جدول ه: آزمونهاى پايدارى نتايج ركرسيون بسامد تغييرات قيمت } \\
\hline$(\boldsymbol{F})$ & $(\boldsymbol{r})$ & $(Y)$ & (1) & \\
\hline & & & $\begin{array}{l}r / r_{Q} \text { * } \\
(r \cdot / 09)\end{array}$ & تورم ماهانه مصرف كننده \\
\hline & & & 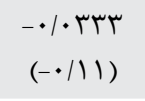 & متغير آستانه تورم ماهانه مصرف كننده \\
\hline & & $\begin{array}{l}\cdot / 9 \uparrow \cdot{ }^{*} \\
(19 / V \Delta)\end{array}$ & & تورم نقطهبهنقطه مصرف كننده \\
\hline & & $\begin{array}{l}-\cdot / 9 r V^{*} \\
(-1 \bowtie / \Delta \&)\end{array}$ & & متغير آستانه تورم نقطهبdنقطه مصرف كننده \\
\hline & 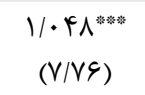 & & & 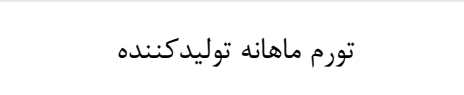 \\
\hline & $\begin{array}{c}-1 / \cdot r V^{* * * w^{*}} \\
(-V / \Delta \Lambda)\end{array}$ & & & متغير آستانه تورم ماهانه توليدكننده \\
\hline $\begin{array}{l}\cdot|9| \Lambda^{* * * * * *} \\
(\mid Y / T Y)\end{array}$ & & & & تورم نقطهبهنقطه توليدكننده \\
\hline $\begin{array}{l}-\cdot \mid \Delta V F^{c * * *} \\
(-|r / \Delta|)\end{array}$ & & & & متغير آستانه تورم نقطهبهنقطه توليدكننده \\
\hline 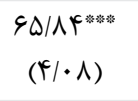 & $\begin{array}{l}T V / T H \\
(I / F T)\end{array}$ & $\begin{array}{c}9 \Delta / \mathcal{F})^{\text {w*w: }} \\
(\mathcal{E} / \mathcal{F} \Psi)\end{array}$ & $\begin{array}{l}\mid r V / V^{w} \\
(V / \Lambda \mid)\end{array}$ & تغييرات نقدينكى روندزدايىشده - \\
\hline $\begin{array}{l}r \cdot / / T \\
(\cdot / \Lambda \cdot)\end{array}$ & $\begin{array}{l}q \varepsilon / \mathbb{R} \varphi^{*} \\
(T / K \cdot)\end{array}$ & $\begin{array}{l}-1 \cdot /{ }^{\prime} \wedge \\
(-\cdot / \mathcal{F})\end{array}$ & $\begin{array}{c}-1 \cdot \Delta / V^{*} \\
(-\Gamma / \Lambda \Delta)\end{array}$ & تغييرات نقدينكى روندزدايىشده + \\
\hline 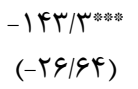 & $\begin{array}{l}-|9| / r^{w * m} \\
(-r \Delta / 9 T)\end{array}$ & 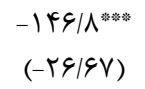 & $\begin{array}{l}-\mid F Y / Y^{* \cdots \cdots} \\
(-Y Y / \cdot \Lambda)\end{array}$ & 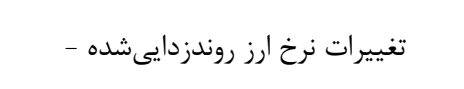 \\
\hline
\end{tabular}


ادامه جدول ه: آزمونهاى هايدارى نتايج ركرسيون بسامد تغييرات قيمت

\begin{tabular}{|c|c|c|c|c|}
\hline$(\boldsymbol{f})$ & (r) & (r) & (1) & \\
\hline $\begin{array}{l}V / / 9 \Delta^{*} \\
(\mid T / T \varphi)\end{array}$ & 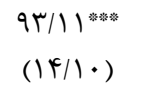 & 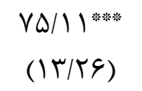 & 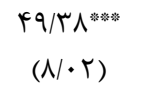 & تغييرات نرخ ارز روندزدايىشده + \\
\hline $\begin{array}{l}-\& Y \Lambda / \Lambda^{*} \\
(-Y Y / q F)\end{array}$ & $\begin{array}{l}-\Delta 9 Y / \Delta^{* * *} \\
(-Y Y / Y Y)\end{array}$ & $\begin{array}{l}-\varepsilon \mid \varepsilon / \Lambda^{* * *} \\
(-r \Delta \cdot / 1 \cdot)\end{array}$ & $\begin{array}{l}-\Delta \wedge \Delta / V^{* * * * *} \\
(-\mu \Psi / \cdot \Delta)\end{array}$ & تغييرات توليد روندزدايىشده - \\
\hline $\begin{array}{l}\mid \mathcal{F} \cdot N / q^{*} \\
(Y V / \mid \mathcal{F})\end{array}$ & 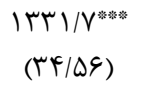 & 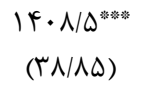 & 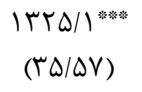 & تغييرات توليد روندزدايىشده + \\
\hline 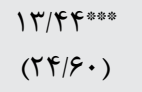 & 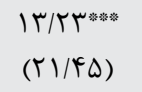 & 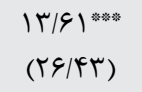 & 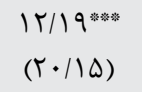 & حجم واردات \\
\hline 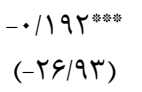 & $\begin{array}{l}-\cdot / \mid \Delta \varphi^{*} \\
(-r V / \Delta \mid)\end{array}$ & 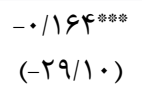 & 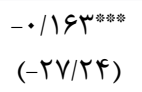 & رشد قيمت نفت \\
\hline 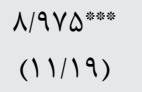 & $\begin{array}{l}11 / \cdot \Delta^{* * * *} \\
(r \cdot / \cdot 9)\end{array}$ & $\begin{array}{l}\Lambda / \backslash \Lambda \Lambda^{*}{ }^{* * * *} \\
(\mid Y / \& \vee)\end{array}$ & 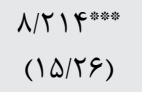 & متغير مجازى هدفمندى يارانهها \\
\hline 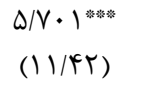 & $\begin{array}{l}V / F \mid \varphi^{*} \\
(|f /| \mid)\end{array}$ & 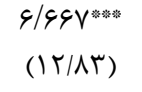 & $\begin{array}{l}q / V F \mid \text { : } \\
(\mid r / \cdot \Delta)\end{array}$ & متغير مجازى تحريمم \\
\hline $\begin{array}{l}-9 / \mathcal{\leftarrow}\left\lceil\Delta^{*}\right. \\
(-1 \cdot|\uparrow|)\end{array}$ & 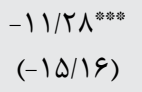 & $\begin{array}{l}-9 / V V Y^{*} \\
(-1 Y / \Delta \Lambda)\end{array}$ & 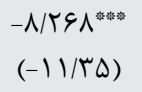 & متغير مجازى دولت يازدهم \\
\hline $\begin{array}{l}-\Lambda \Lambda / \Delta \Delta^{* * * *} \\
\left.(-\mid \Lambda / \Lambda)^{*}\right)\end{array}$ & $\begin{array}{l}\Lambda|/ V|^{*} \\
(\mid \Delta / 9 V)\end{array}$ & 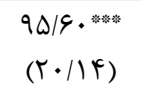 & 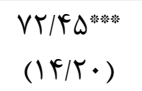 & ثابت \\
\hline rqマ^ & rqv^ & rqv^ & rqマ^ & تعداد مشاهده \\
\hline$\cdot \mid \Delta \Delta \varphi$ & $\cdot \mid \Delta F \varepsilon$ & - IDST & - |D९G & $\mathrm{R} 2$ \\
\hline
\end{tabular}




\begin{tabular}{|c|c|c|c|c|}
\hline \multicolumn{5}{|c|}{ جدول \&: آزمونهاى بايدارى نتايج ركرسيون اندازه تغييرات قيمت } \\
\hline$(\boldsymbol{f})$ & $(\boldsymbol{\mu})$ & (r) & $(1)$ & \\
\hline & & & $\begin{array}{l}\cdot / \Delta Y \Delta^{* w *} \\
(G Y / T F)\end{array}$ & تورم ماهانه مصرف كننده \\
\hline & & 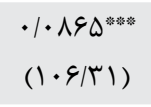 & & تورم نقطهبهنقطه مصرف كننده \\
\hline & 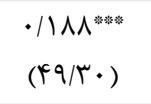 & & & تورم ماهانه توليدكننده \\
\hline 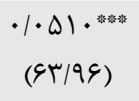 & & & & تورم نقطهبهنقطه توليدكننده \\
\hline $\begin{array}{l}-Y \Lambda / I Y^{* * * * *} \\
(-\Delta Y / Y \mathcal{F})\end{array}$ & 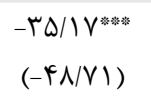 & $\begin{array}{l}-r V / 1 \cdot{ }^{*} \\
(-r \& / q r)\end{array}$ & $\begin{array}{l}-r r / 99^{* * *} \\
(-r Y / Y q)\end{array}$ & تغييرات نقدينكَى روندزدايىشده - \\
\hline $\begin{array}{l}\Delta \cdot / \Delta \cdot \cdots \\
(\Delta I / T T)\end{array}$ & $\begin{array}{l}\Delta F / 9 \Lambda^{* * * *} \\
(\Delta F / Y \Lambda)\end{array}$ & $\begin{array}{l}r \mathcal{F} / \mathcal{F} \Delta^{* 0 *} \\
(\Psi \mathcal{F} / \mid \Psi)\end{array}$ & $\begin{array}{l}K F / V V^{* * *} \\
(Y K / G \Lambda)\end{array}$ & تغييرات نقدينكى روندزدايىشده + \\
\hline 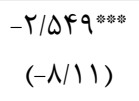 & 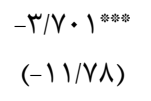 & 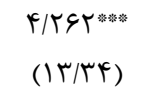 & 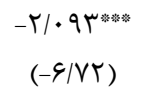 & تغييرات نرخ ارز روندزدايىشده - \\
\hline $\begin{array}{l}9 / \Delta ९ 9^{* * * * * *} \\
((\& / \mid Q)\end{array}$ & $\begin{array}{l}f / 999^{* * * *} \\
(\mid Y / \Lambda \cdot)\end{array}$ & $\begin{array}{l}\cdot|4| \mid \\
(1 / \cdot 9)\end{array}$ & $\begin{array}{l}F / q T I^{*} \text { w } \\
(\mid r / T I)\end{array}$ & تغييرات نرخ ارز روندزدايىشده + \\
\hline 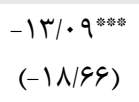 & $\begin{array}{l}\cdot / q r q \\
(1 / F T)\end{array}$ & $\begin{array}{l}-1 \cdot / I V^{*} \\
(-1 Q / Y Y)\end{array}$ & $\begin{array}{l}-\cdot / \cdot r F . \\
(-\cdot / \cdot \Delta)\end{array}$ & تغييرات توليد روندزدايىشده - \\
\hline 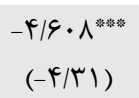 & 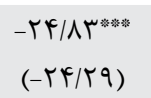 & $\begin{array}{l}\cdot / \& V V \\
(\cdot / \& \varepsilon)\end{array}$ & $\begin{array}{l}-Y \cdot / 1 Q^{*} \\
(-19 / \vee \wedge)\end{array}$ & تغييرات توليد روندزدايىشده + \\
\hline
\end{tabular}


ادامه جدول \&: آزمونهاى بِايدارى نتايج ركرسيون اندازه تغييرات قيمت

\begin{tabular}{|c|c|c|c|c|}
\hline$(\boldsymbol{F})$ & (r) & $(Y)$ & (1) & \\
\hline 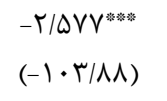 & 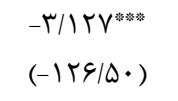 & 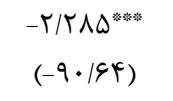 & 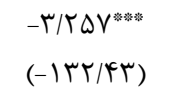 & 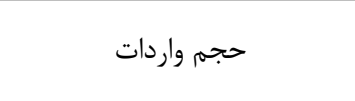 \\
\hline $\begin{array}{c}-\cdot \cdot \cdot \Delta \Delta q^{\text {絭漛 }} \\
(-r \cdot / \cdot \Lambda)\end{array}$ & 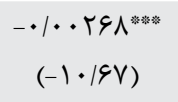 & $\begin{array}{c}-\cdot / \cdot r \cdot l^{*} \\
(-\Lambda / I T)\end{array}$ & 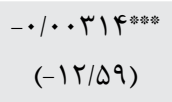 & رشد قيمت نفت \\
\hline 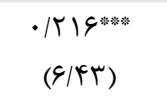 & 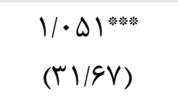 & 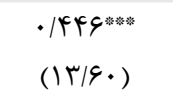 & $\begin{array}{l}\cdot|Y| 9^{* *} \\
(Y Y / Q V)\end{array}$ & متغير مجازى هدفمندى يارانهها \\
\hline $\begin{array}{l}-\cdot / T \& V^{*} \\
(-1 \cdot / \cdot 1)\end{array}$ & 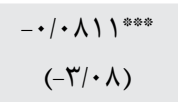 & $\begin{array}{c}-\cdot / 49 \cdot * * * w \\
(-9 / 19)\end{array}$ & $\begin{array}{c}-\cdot / 19 \cdot{ }^{* * * *} \\
(-V / 1 Y)\end{array}$ & متغير مجازى تحريم \\
\hline 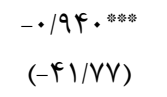 & 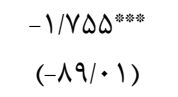 & $\begin{array}{l}-1 / \cdot f f^{c *} \\
(-\Delta 1 / q \mu)\end{array}$ & 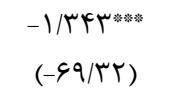 & متغير مجازى دولت يازدهم \\
\hline $\begin{array}{l}r \mid / r K^{*} \\
(1 \cdot F / \Delta F)\end{array}$ & 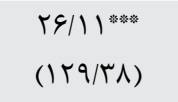 & $\begin{array}{l}\mid \Lambda / \mathcal{F} Y^{*} \\
(\Lambda \Lambda / Y \Lambda)\end{array}$ & $\begin{array}{l}r V / K q * \text { *:* } \\
(\mid r G / K \cdot)\end{array}$ & ثابت \\
\hline 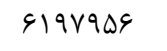 & 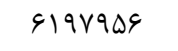 & 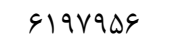 & 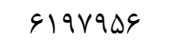 & تعداد مشاهده \\
\hline$\cdot / \cdot r \wedge$ & $\cdot / \cdot r \Lambda$ & $\cdot / \cdot r q$ & $\cdot / \cdot r q$ & $\mathrm{R} 2$ \\
\hline
\end{tabular}

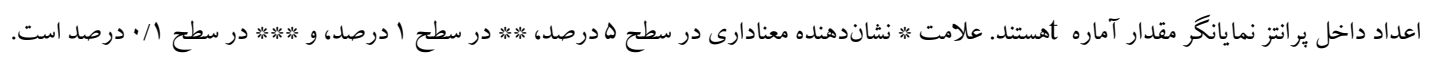




\section{بحث و نتيجه}

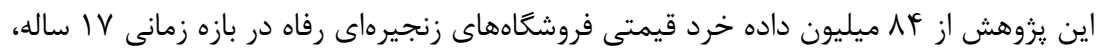

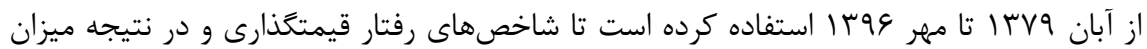
جسبندگى قيمت كالاها را محاسبه كند و جگَونكى تاثيريذيرى اين شاخصها را از نرخ تورم و متغيرهاى كلان اقتصادى بررسى نمايد.

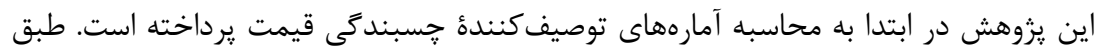
محاسبات صورت

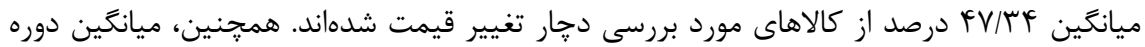

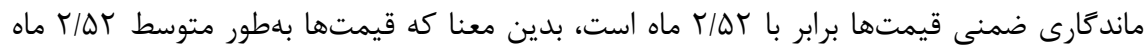

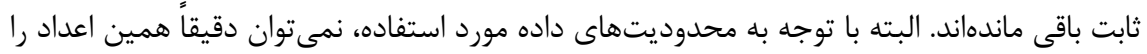
به كل قيمتها در كشور تعميم داد، اما با توجه به اين محدوديت كه فروشگاه رفاه شامل كالاهايى است كه قيمت آنها بهطور دولتى و سراسرى تعيين مىشود، مىتوان كَت كه دوره ماندگًارى قيمت

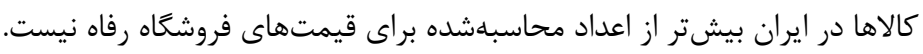

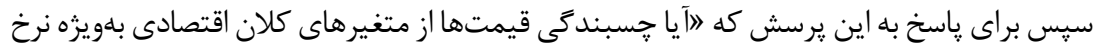
تورم اثر مىيذيرد يا خير؟《، بسامد تغيير قيمت و اندازه تغيير قيمت به عنوان متغير وابسته به همراه

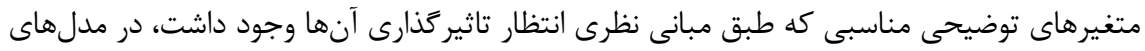

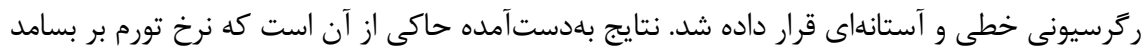
و اندازه تغييرات قيمت اثر مثبت و معنادارى دارد. محاسبات نشان مى دهد كه بين بسامد تغيير قيمت

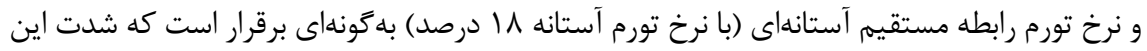

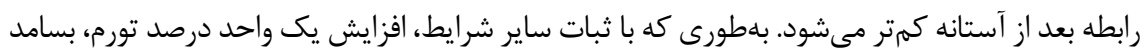

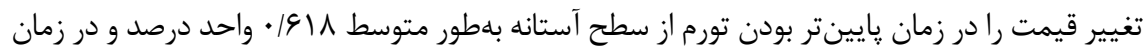
بالاتر بودن تورم از سطح آستانه باطور متوسط بf • • • • واحد درصد افزايش مى دهد. بر اساس اين، به نظر مىرسد كه در زمانهاى تورم بالا، قيمتخذاران جون به كاهش قدرت خريد مردم در سطح جامعه واقفند،

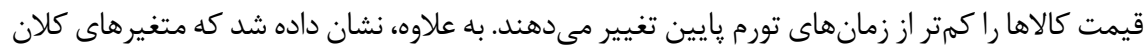

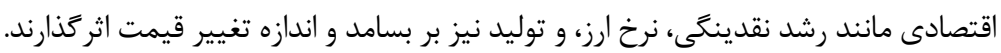
طبق رگرسيونهاى انجامشده مشخص شد كه نقدينگى اثر مثبت بر "ابسامده تغييرات قيمت 
دارد، بهطورى كه اين اثر در زمانهايى كه خالص نقدينكى در حال افزايش است شديدتر است. توليد در زمانهاى ركود اثر منفى و در زمانهاى رونق اثر مثبت قابلتوجهى بر "بسامده تغييرات

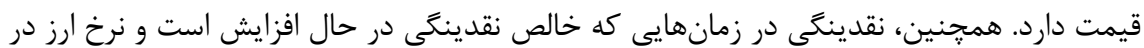

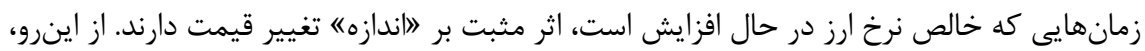

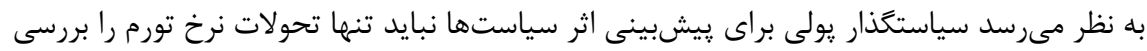
كند، بلكه لازم است به تغييرات نقدينكى، توليد، و نرخ ارز نيز توجه ويزماى داشته باشد. نتايج مذكور نسبت به نرخ تورمهاى ماهانه و نقطهبهنقطه مصرفكننده و توليدكننده يايدار است. در نهايت كفتنى است كه تخمينهاى انجامشده با محدوديتهاى دادهاى همراه بوده كه اين محدوديتها به تشريح در بخش محدوديتهاى داده در ييوست مورد بحث قرار گرفته است.

با تشكر و قدردانى از مديريت دفتر مركزى فروشگاه رفاه كه با در اختيار قرار دادن دادههاى مورد

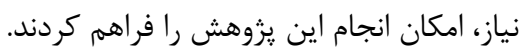

الف) انغَليسى

Alvarez, F., Beraja, M., Gonzalez-Rozada, M., \& Neumeyer, P. A. (2019). From Hyperinflation to Stable Prices: Argentina's Evidence on Menu Cost Models. The Quarterly Journal of Economics, 134(1), 451-505. https://doi.org/10.1093/qje/qjy022

Alvarez, F., Lippi, F., \& Passadore, J. (2017). Are State-and Time-Dependent Models Really Different? NBER Macroeconomics Annual, 31(1), 379-457. https://doi.org/10.1086/690243

Barro, R. J. (1972). A Theory of Monopolistic Price Adjustment. The Review of Economic Studies, 39(1), 17-26. https://doi.org/10.2307/2296440

Bayat, S., \& Jabal Ameli, P. (2019). Policy Requirements under Different Macroeconomic Conditions: An Application of Micro CPI Data. Journal of Monetary \& Banking Research, 12(39), 1-22. http://jmbr.mbri.ac.ir/article-1-1146-fa.html

Bayat, S., \& Madanizadeh, S. A. (2019). The Threshold Reaction of Price Setting Behavior Indexes to Inflation Rate Changes: An Application of Price Micro Information to Understand the Changes of Price Rigidity Degree. Quarterly Journal of Economic Research and Policies, 27(90), 7-56. http://qjerp.ir/article-1-2136-en.html 
Bils, M., \& Klenow, P. J. (2004). Some Evidence on the Importance of Sticky Prices. Journal of Political Economy, 112(5), 947-985. https://doi.org/10.1086/422559

Calvo, G. A. (1983). Staggered Prices in a Utility-Maximizing Framework. Journal of Monetary Economics, 12(3), 383-398. https://doi.org/10.1016/0304-3932(83)90060-0

Gagnon, E. (2009). Price Setting During Low and High Inflation: Evidence from Mexico. The QuarterlyJournalofEconomics, 124(3),1221-1263.https://doi.org/10.1162/qjec.2009.124.3.1221

Golosov, M., \& Lucas Jr, R. E. (2007). Menu Costs and Phillips Curves. Journal of Political Economy, 115(2), 171-199. https://doi.org/10.1086/512625

Hemmaty, M., \& Bayat, S. (2013). Price Setting in Iran: Some Stylized Facts from CPI Micro Data. Journal of Money and Economy, 8(1), 75-108.

Karami, H., Bayat, S., \& Bahador, A. (2016). Policy Making Requirements for Inflation Targeting Framework in Iran: Applying SVARX Model. The Journal of Planning and Budgeting, 20(4), 31-54. http://jpbud.ir/article-1-1150-fa.html

Lucas Jr, R. E. (1996). Nobel Lecture: Monetary Neutrality. Journal of Political Economy, 104(4), 661-682. https://doi.org/10.1086/262037

McCandless, G. T., \& Weber, W. E. (1995). Some Monetary Facts. Federal Reserve Bank of Minneapolis Quarterly Review, 19(3), 2-11.

Nakamura, E., \& Steinsson, J. (2008). Five Facts about Prices: A Reevaluation of Menu Cost Models. The Quarterly Journal of Economics, 123(4), 1415-1464. https://doi.org/10.1162/qjec.2008.123.4.1415

Sargent, T. J., \& Wallace, N. (1975). "Rational" Expectations, the Optimal Monetary Instrument, and the Optimal Money Supply Rule. Journal of Political Economy, 83(2), 241-254. https://doi.org/10.1086/260321

Sargent, T. J., \& Wallace, N. (1976). Rational Expectations and the Theory of Economic Policy. Journal of Monetary Economics, 2(2), 169-183. https://doi.org/10.1016/0304-3932(76)90032-5

Seighalani, S., \& Rahmani, T. (2018). An Analysis of the Relationship between Monetary Shocks and Inflation Rate of CPI Components for Testing Price Stickiness. The Journal of Planning and Budgeting, 22(3), 3-22. http://jpbud.ir/article-1-1742-fa.html

Sheshinski, E., \& Weiss, Y. (1977). Inflation and Costs of Price Adjustment. The Review of Economic Studies, 44(2), 287-303. https://doi.org/10.2307/2297067

Taylor, J. B. (1980). Aggregate Dynamics and Staggered Contracts. Journal of Political Economy, 88(1), 1-23. https://doi.org/10.1086/260845

Teles, P., \& Zhou, R. (2005). A Stable Money Demand: Looking for the Right Monetary Aggregate. Federal Reserve Bank of Chicago, 29(I), 50-63.

Wulfsberg, F. (2009). Price Adjustments and Inflation-Evidence from Norwegian Consumer Price Data 1975-2004: Working Paper, No. 2009/11. http://hdl.handle.net/11250/2577448

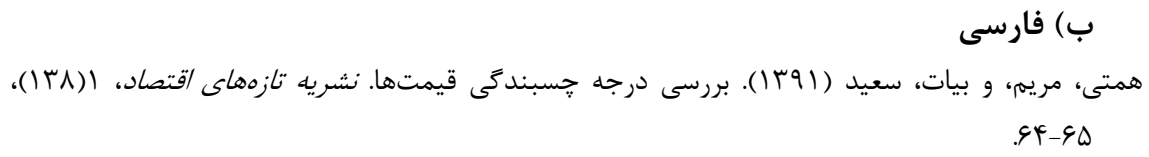




\section{ييوست}

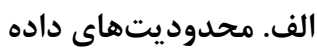

در اين بخش، محدوديتهايى كه در دادهاى مورد استفاده وجود دارد، شرح داده مى شود:

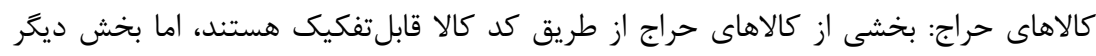

$$
\text { قابلشناسايى نيستند. }
$$

اقلام دولتى و غيردولتى: كالاهاى عرضهشده در فروشكاههاى رفاه از نظر سيستم قيمتكذارى دو

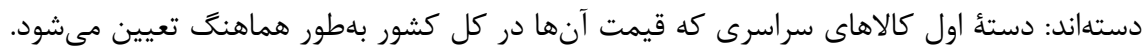

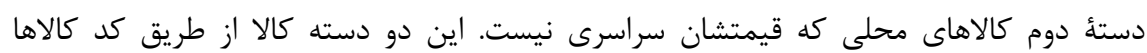

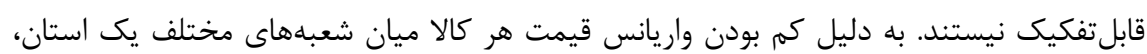

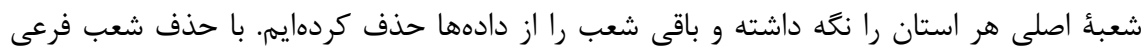

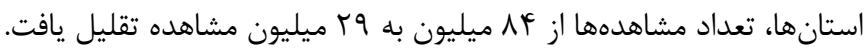

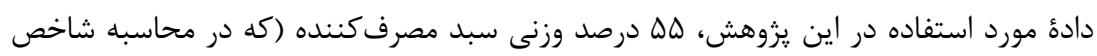

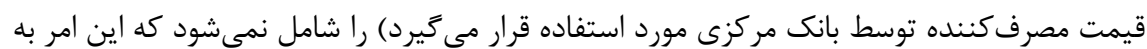

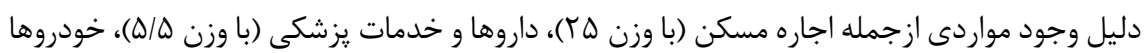

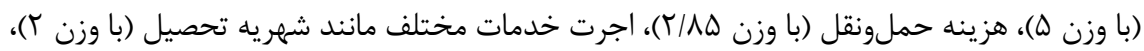

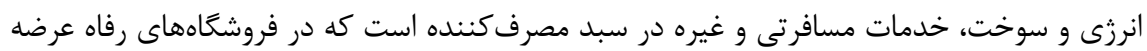

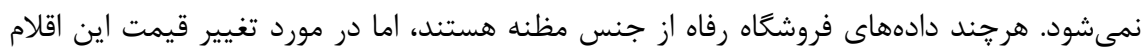

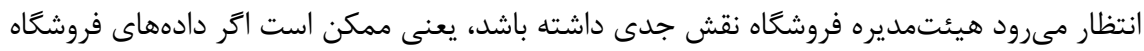

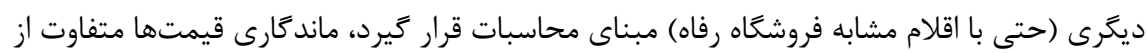

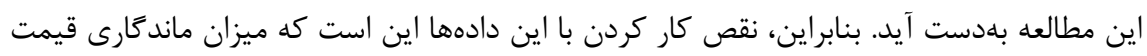

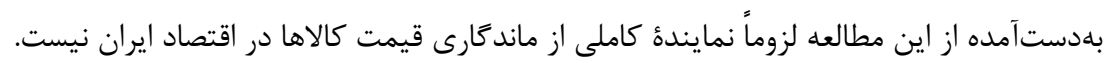

\section{ب. باكسازى داده}

اين بخش نحوه پاكسازى دادهها قبل از انجام محاسبات را شرح مىدهد. براى جلوكيرى از ايجاد

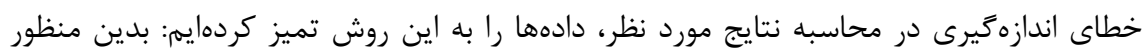


مقاديرى از متغيرها كه به دليل خطاى إراتور يا هر دليل ديغرى اشتباه ثبت شده بود شناسايى شد.

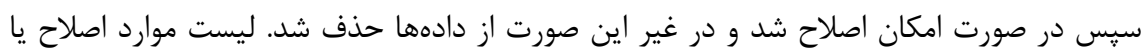
حذفشده به شرح زير است:

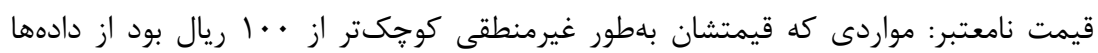

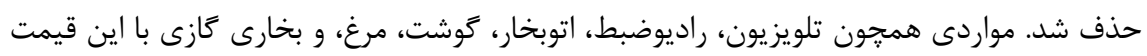

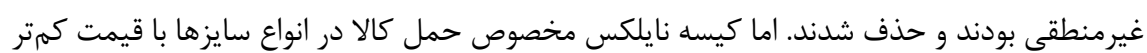

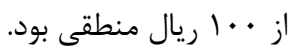
كد كالاى نامعتبر: مواردى كه كد كالاى آنها مجموعهاى از اشكال نامفهوم بود از دادهها حذف بود تاريخ نامعتبر: مواردى كه در آنها عددى خارج از بازه ا تا | I براى ماه ثبت شده بود در صورت

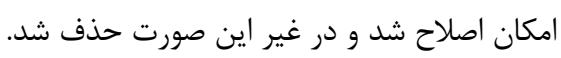

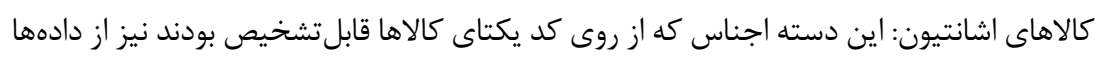

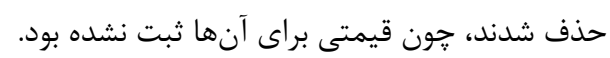

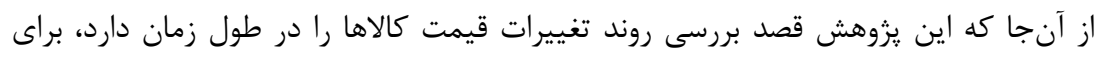

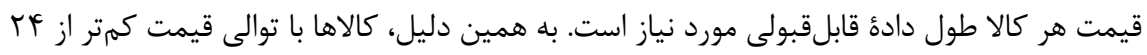

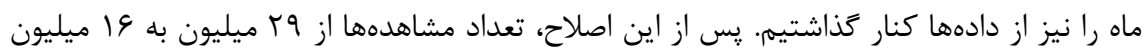
مشاهده تقليل يافت.

\section{ب. خلاصه آمارى از داده}

يكى از موضوعات قابل توجه كه در دادها مشاهده مى شود، وجود ناهمكونى بسامد تغييرات قيمت در ميان گروههاى مختلف كالايى است. ميانگين و انحراف استاندارد بسامد تغييرات قيمت و اندازه

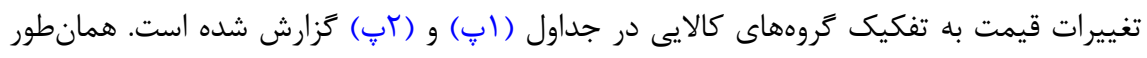

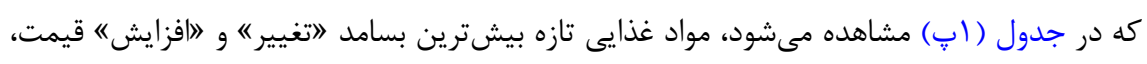

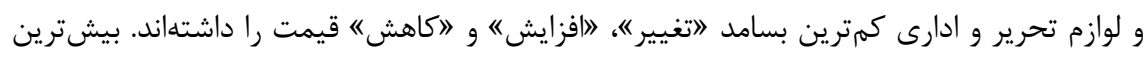
بسامد 》كاهش) قيمت مربوط به گروه يوشاك بوده است. 
جدول ابٍ: خلاصه آمارى بسامد تغييرات قيمت به تفكيك كروههاى كالا

\begin{tabular}{|c|c|c|c|c|c|c|c|}
\hline كل & يوشاك & غذازه & خوراكى آشاميدنى & خانكَى و & تحرير و & بهداشتى آرايشى & \\
\hline $\begin{array}{l}F \Delta, V Y \\
(Y Y, Q Y)\end{array}$ & $\begin{array}{l}r \Delta, \cdot V \\
(r \Delta, \cdot r)\end{array}$ & $\begin{array}{l}\Delta r, r r \\
(Y \Lambda, r V)\end{array}$ & $\begin{array}{l}4 q, . q \\
(r ., q \varphi)\end{array}$ & $\begin{array}{l}F G, r G \\
(Y F, \mid r)\end{array}$ & $\begin{array}{l}r F, q) \\
(r \mid, q r)\end{array}$ & $\begin{array}{l}q \varphi, q) \\
(Y \Psi, \Delta \Psi)\end{array}$ & فركانس تغيير قيمت \\
\hline $\begin{array}{l}r V, \Delta V \\
(Y T, Y G)\end{array}$ & $\begin{array}{l}r \Delta, r . \\
(r, \Delta, \Delta)\end{array}$ & $\begin{array}{l}r Y, q 9 \\
(Y \varphi, 19)\end{array}$ & $\begin{array}{l}r \mid, . F \\
(19, \Delta \Delta)\end{array}$ & $\begin{array}{l}r \wedge, . Y \\
(Y Y, . q)\end{array}$ & $\begin{array}{l}\text { 19,rV } \\
(19, \cdot r)\end{array}$ & $\begin{array}{l}r \wedge, \varphi \varphi \\
(r /, 1 \cdot)\end{array}$ & فركانس افزايش قيمت \\
\hline $\begin{array}{l}\mid 1,19 \\
(Y,, \mid 1)\end{array}$ & $\begin{array}{l}\text { 19,VV } \\
(r r, Q Y)\end{array}$ & $\begin{array}{l}19, r F \\
(r \Delta, r q)\end{array}$ & $\begin{array}{l}|\Lambda, \cdot| \\
(1 \Lambda, F \vee)\end{array}$ & $\begin{array}{l}\text { IA,rr } \\
(r, \Delta r)\end{array}$ & $\begin{array}{l}I Q, Y F \\
(Y \cdot, \cdot r)\end{array}$ & $\begin{array}{l}\mid \Lambda, r \Delta \\
(r \cdot, F Y)\end{array}$ & فر كانس كاهش قيمت \\
\hline $\begin{array}{l}f, 199 \\
(\Delta, \Delta \wedge \vee)\end{array}$ & $\begin{array}{l}\varphi, r q q \\
(\xi, q r \cdot)\end{array}$ & $\begin{array}{l}f, q \wedge l \\
(q, \mid F \vee)\end{array}$ & $\begin{array}{l}r, Q T \mid \\
(1, \Delta F \&)\end{array}$ & $\begin{array}{l}r, \Delta \mid . \\
(r, \mid r q)\end{array}$ & $\begin{array}{c}q, \Delta \wedge r \\
(\vee, I \vee T)\end{array}$ & $\begin{array}{l}r, r \wedge \Lambda \\
(r, I r \Delta)\end{array}$ & دوره ماندكارى قيمت \\
\hline $1 \pi \mid 1$ & & & & & & & تعداد مشاهده \\
\hline
\end{tabular}

جدول بپ: خلاصه آمارى اندازه تغييرات قيمت به تفكيك تروههاى كالا

\begin{tabular}{|c|c|c|c|c|c|c|c|}
\hline كل & يوشاى & غذازيى & خوراكى آشاميدنى & خانعى و & تحرير و & بهداشتى & \\
\hline $\begin{array}{l}\text { I,AVV } \\
(I Y, Y \Lambda)\end{array}$ & $\begin{array}{l}., 991 \\
(q, Y \mid Y)\end{array}$ & $\begin{array}{l}F, r \& Y \\
(1 \cdot V, q)\end{array}$ & $\begin{array}{l}r, Y \cdot q \\
(1 \cdot, q \Lambda)\end{array}$ & $\begin{array}{l}1, \wedge F Y \\
(I T, \wedge Y)\end{array}$ & $\begin{array}{l}1,19 r \\
(r \cdot, Y 1)\end{array}$ & $\begin{array}{l}1,9 \wedge r \\
(9, \wedge \vee r)\end{array}$ & اندازه تغيير قيمت \\
\hline $\begin{array}{l}\Delta, g F V \\
(|F,| r)\end{array}$ & $\begin{array}{l}f, r q q \\
(1 ., 9 q)\end{array}$ & $\begin{array}{l}q, F \Delta \mid \\
(\mid r V, F)\end{array}$ & $\begin{array}{l}\Delta, \wedge \& \mid \\
(\mid Y, . F)\end{array}$ & $\begin{array}{l}\Delta, \varphi q . \\
(1 \Delta, r r)\end{array}$ & $\begin{array}{l}F, Y r \Lambda \\
(Y V, \Delta r)\end{array}$ & $\begin{array}{l}0,9 \cdot 9 \\
(1 \cdot, 4 \cdot)\end{array}$ & اندازه افزايش قيمت \\
\hline $\begin{array}{l}r, q r) \\
(F, F \vee r)\end{array}$ & $\begin{array}{l}r, 994 \\
(r, \wedge 9 \%)\end{array}$ & $\begin{array}{l}r, \wedge \wedge \Delta \\
(\Psi, \mid r \mu)\end{array}$ & $\begin{array}{l}r, q \mu q \\
(\xi, r \Delta \cdot)\end{array}$ & $\begin{array}{l}r, V \Delta F \\
(F, \ldots F)\end{array}$ & $\begin{array}{l}r, Y \Delta T \\
(r, T \wedge \Delta)\end{array}$ & $\begin{array}{l}\text { F,IVA } \\
(\mathcal{F}, q Y r)\end{array}$ & اندازه كاهش قيمت \\
\hline VVG৭TDG & & & & & & & تعداد مشاهده \\
\hline
\end{tabular}

با توجه به جدول (rاب)، بيشترين و كمترين اندازه اتغييره قيمت بلهترتيب مربوط به گروه مواد

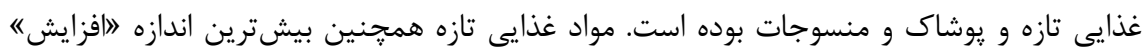

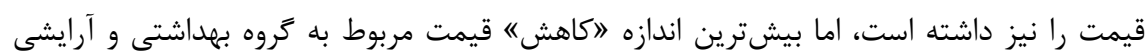
بوده است. 


\section{ت. جداول ركرسيون}

در راستاى كشف رابطه نرخ تورم با بسامد تغيير قيمت و همجنين تاثير متغيرهاى كلان اقتصادى

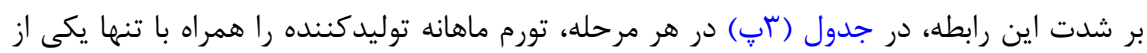

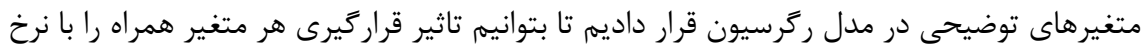

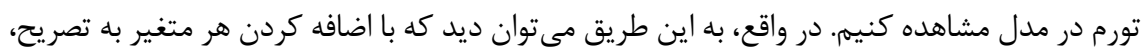

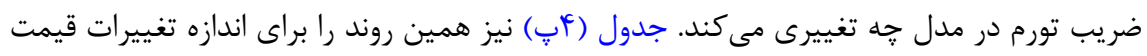
نشان مىدهد. 
جدول ساب: نتايج ركرسيون بسامد تغييرات قيمت بر هر متغير توضيحى به صورت جداكانه

\begin{tabular}{|c|c|c|c|c|c|c|c|c|c|}
\hline (9) & $(\Lambda)$ & $(V)$ & (9) & $(\Delta)$ & $(\boldsymbol{f})$ & $(\Psi)$ & $(Y)$ & (1) & \\
\hline \multirow[t]{10}{*}{ 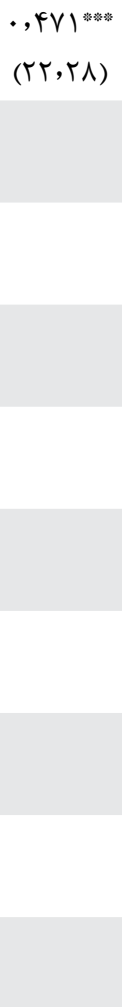 } & $\begin{array}{l}\cdot, \text {, TFF } \\
(1, \text { MT) }\end{array}$ & 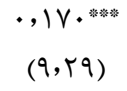 & 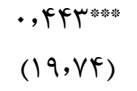 & 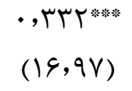 & 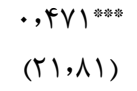 & 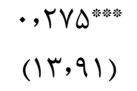 & $\begin{array}{l}\cdot, f \mid l^{\text {wow }} \\
(19, \Delta \Delta)\end{array}$ & 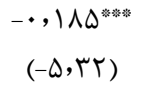 & تورم نقطهبهنقطه توليدكنـنده \\
\hline & & & & & & & & $\begin{array}{l}\cdot, \wedge \mid Q^{* * * * *} \\
(\mid \Delta, \vee \wedge)\end{array}$ & متغير آستانه تورم نقطهبهنقطه \\
\hline & & & & & & & 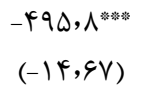 & & غييرات نقدينكَى روندزدايىشده - \\
\hline & & & & & & & $\begin{array}{l}\Delta \varphi q, r^{*} \\
(1 \cdot, \vee \vee *\end{array}$ & & غييرات نقدينكَى روندزدايىشده + \\
\hline & & & & & & $\begin{array}{l}-Y V V, g^{* * * * *} \\
(-Y \Delta, r T)\end{array}$ & & & تغييرات نرخ ارز روندزدايىشده - \\
\hline & & & & & & 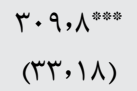 & & & تغييرات نرخ ارز روندزدايىشده + \\
\hline & & & & & 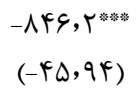 & & & & تغييرات توليد روندزدايىشده - \\
\hline & & & & & 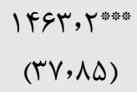 & & & & تغييرات توليد روندزدايىشده + \\
\hline & & & & 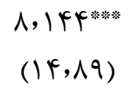 & & & & & حجم واردات \\
\hline & & & $\begin{array}{l}-\cdot, \mid r Y^{* * * *} \\
(-Y T, \Delta Y)\end{array}$ & & & & & & رشد قيمت نفت \\
\hline
\end{tabular}


ادامه جدول ساب: نتايج ركرسيون بسامد تغييرات قيمت بر هر متغير توضيحى به صورت جداكانه

\begin{tabular}{|c|c|c|c|c|c|c|c|c|c|}
\hline (9) & $(\Lambda)$ & $(V)$ & (9) & (b) & (i) & (ए) & $(T)$ & (1) & \\
\hline & & 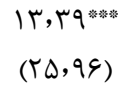 & & & & & & & متغير مجازى هدفمندى يارانهها \\
\hline & 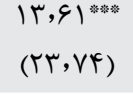 & & & & & & & & متغير مجازى تحريم \\
\hline $\begin{array}{l}1 \cdot, \Delta q^{\text {* }} \\
(1 \vee, \curlyvee q)\end{array}$ & & & & & & & & & متغير مجازى دولت يازدهم \\
\hline $\begin{array}{l}r \Delta, r \varphi^{* *:} \\
(r q, \varnothing \mathcal{G})\end{array}$ & 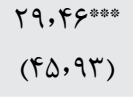 & $\begin{array}{l}r G, r Q^{* * * *} \\
(Y V, q \vee)\end{array}$ & 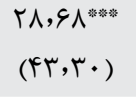 & $\begin{array}{c}-Y Y, Y Q^{* * * *} \\
(-G, \vee q)\end{array}$ & 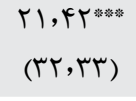 & $\begin{array}{l}r \Delta, \Delta V^{* * * *} \\
(r \Delta, q \cdot)\end{array}$ & $\begin{array}{l}r \Delta, \cdot r^{*} \\
(r, q u)\end{array}$ & $\begin{array}{l}r F, V V^{*} \\
(Y \&, I V)\end{array}$ & ثابت \\
\hline$\Delta \Delta F \wedge$ & $\Delta Q F \Lambda$ & $\Delta D F \Lambda$ & $\Delta \Delta F \wedge$ & $Y \Delta \mid$. & 0.19 & $\Delta \Delta F \Lambda$ & DrGA & $\Delta \Delta F \wedge$ & تعداد مشاهده \\
\hline Vוז, & וזr,. &.,$r \Delta \Delta$ & . & $\cdot, r \cdot 1$ & $\cdot, 4 \cdot \varphi$ & . & عוצ., & ., rqr & $\mathrm{R} 2$ \\
\hline
\end{tabular}

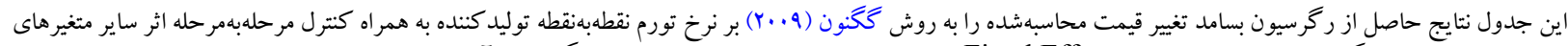

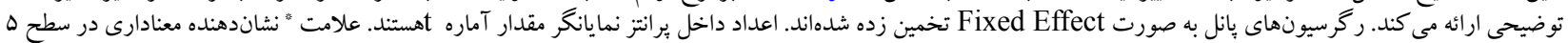

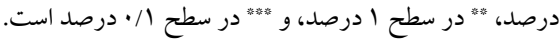


جدول †اب: نتايج ركرسيون اندازه تغييرات قيمت بر هر متغير توضيحى به صورت جداكانه

\begin{tabular}{|c|c|c|c|c|c|c|c|c|c|c|}
\hline$(1 \cdot)$ & (9) & (^) & (V) & (9) & $(\Delta)$ & $(\boldsymbol{F})$ & (W) & (Y) & (1) & \\
\hline $\begin{array}{l}\cdot, \uparrow \& V^{* 3 *} \\
(\vee \&, \& \wedge)\end{array}$ & $\begin{array}{l}\cdot, \Delta \& \Lambda^{* \text { *wow }} \\
(q \cdot, \cdot \vee \vee)\end{array}$ & 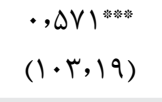 & 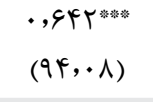 & $\begin{array}{l}\cdot, \Delta \vee G^{* \text { *as }} \\
(q \vee, Y Y)\end{array}$ & 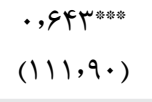 & 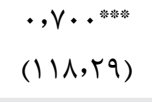 & 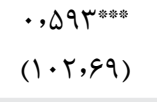 & $\begin{array}{l}., 919^{\text {*was }} \\
(1.9, \Delta Y)\end{array}$ & $\begin{array}{l}\cdot, 9 \cdot \Lambda^{* \text { *was }} \\
(1 \cdot 9, V Y)\end{array}$ & تورم ماهانه \\
\hline \multirow[t]{8}{*}{$\begin{array}{c}-\cdot, \cdot r \vee Y^{*} \\
(-\Delta \vee, \zeta \wedge)\end{array}$} & 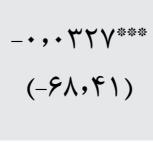 & $\begin{array}{c}-\cdot, \cdot r r \Lambda^{* * * * *} \\
(-V \mathcal{F}, q \Lambda)\end{array}$ & $\begin{array}{c}-\cdot, r V \cdot V^{* * *} \\
(-V \mid, F r)\end{array}$ & $\begin{array}{c}-\cdot, r \& q^{* * *} \\
(-\Delta V, r V)\end{array}$ & $\begin{array}{c}-\cdot,+f r r^{*} \\
(-91,9 \Delta)\end{array}$ & $\begin{array}{c}-\cdot,+q \vee^{* * * *} \\
(-\wedge \uparrow, f \mid)\end{array}$ & 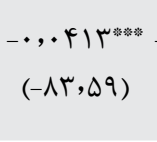 & 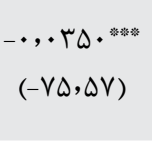 & 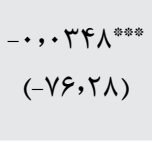 & تورم ماهانه \\
\hline & & & & & & & & $\begin{array}{l}-r \mathcal{Y}, \vee G^{* * *} \\
(-G \Psi, \vee \wedge)\end{array}$ & & تغييراتنقدينكَى \\
\hline & & & & & & & & $\begin{array}{l}91, \Delta \Lambda^{* * * * *} \\
(\vee \backslash, \wedge r)\end{array}$ & & 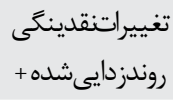 \\
\hline & & & & & & & 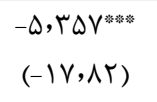 & & & روندييرات نرخ ارز \\
\hline & & & & & & & $\begin{array}{l}11,9 r^{* * * *} \\
(1), \vee \wedge)\end{array}$ & & & تغييرات نرخ ارز \\
\hline & & & & & & 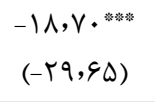 & & & & روندييرات توليد \\
\hline & & & & & & $\begin{array}{l}1 \cdot, q V^{* * * *} \\
(I Y, F Y)\end{array}$ & & & & روندييرات توليد \\
\hline & & & & & 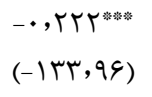 & & & & & رشد اقتصادى \\
\hline
\end{tabular}


ادامه جدول †ب: نتايج ركرسيون اندازه تغييرات قيمت بر هر متغير توضيحى به صورت جداكانه

\begin{tabular}{|c|c|c|c|c|c|c|c|c|c|c|}
\hline (1.) & (9) & $(\Lambda)$ & $(\mathrm{V})$ & (9) & (ه) & $(\boldsymbol{f})$ & $(r)$ & $(r)$ & (1) & \\
\hline & & & & 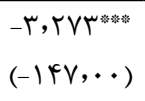 & & & & & & حجم واردات \\
\hline & & & $\begin{array}{c}-\cdot, \cdot r V Y^{*} \\
(-\mid r, \Delta \Delta)\end{array}$ & & & & & & & رشد قيمت \\
\hline & & 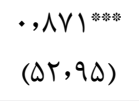 & & & & & & & & هـفنغيرمجازى \\
\hline & $\begin{array}{l}\cdot, r \cdot r^{*}{ }^{*} \\
(r T, \wedge r)\end{array}$ & & & & & & & & & متغير مجازى \\
\hline $\begin{array}{l}-1, \cdot \Delta 1^{* * * *} \\
(-\wedge \Delta, \Delta \Delta)\end{array}$ & & & & & & & & & & دولغير مجازى يازدهم \\
\hline $\begin{array}{l}1,9 \wedge)^{*} \\
(\wedge \Lambda, \cdot \wedge)\end{array}$ & $\begin{array}{l}1, \cdot \wedge 9^{*} \\
(\Delta \wedge, 1 \cdot)\end{array}$ & $\begin{array}{l}\cdot, V \backslash I^{* *} \\
(r, \mid Q)\end{array}$ & $\begin{array}{l}1, \mid \Delta \varphi^{*} \\
(\varphi r, \Delta V)\end{array}$ & $\begin{array}{l}Y V, \mathcal{F} \Lambda^{*} \\
(|\Delta \mathcal{F},| \mathcal{F})\end{array}$ & $\begin{array}{l}|,| \vee \mid \text { **: } \\
(\Delta \varphi, \Delta 9)\end{array}$ & $\begin{array}{l}\cdot, \Delta q)^{* * *} \\
(r \wedge, \& r)\end{array}$ & $\begin{array}{l}1, . G \wedge^{* * *} \\
(\Delta r, \Delta r)\end{array}$ & 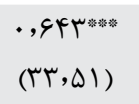 & $\begin{array}{l}1,191^{\text {**:**: }} \\
(99,01)\end{array}$ & ثابت \\
\hline$V V V \cdot \Delta V \Lambda$ & $V V V \cdot \Delta V \Lambda$ & $V V V \cdot \Delta V \wedge$ & $V V V \cdot \Delta V \Lambda$ & $V \cdot \wedge q 4 \cdot \varphi$ & GMATITA & GMATITA & $V V V \cdot \Delta V \Lambda$ & VrTqIFV & $V V V \cdot \Delta V \Lambda$ & تعداد مشاهده \\
\hline.,.$r \wedge$ &.,.$T V$ &.,$\cdot r \Lambda$ &.,$\cdot r V$ &.,.$r q$ &.,$\cdot r V$ & תr., &.,$\cdot T V$ & .,.rG &.,$\cdot T V$ & R2 \\
\hline
\end{tabular}

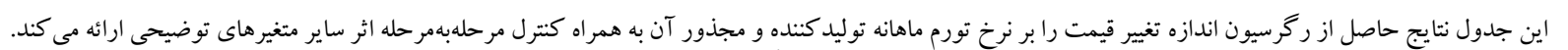

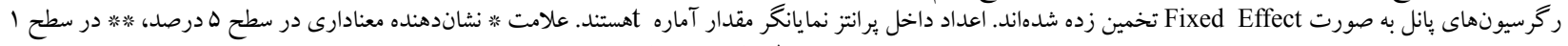
درصد، و \% 